OECDpublishing

\title{
FINANCE AND INCLUSIVE GROWTH
}




\title{
Finance and Inclusive Growth
}

This paper has been prepared by:

\author{
Boris Cournède
}

Oliver Denk

Peter Hoeller

Authorised for publication by Catherine L. Mann,

Chief Economist and G20 Finance Deputy

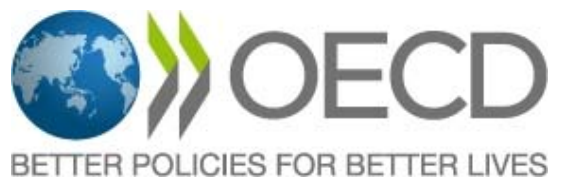


The OECD Economic Policy Paper Series is published on the responsibility of the Secretary-General of the OECD. The opinions expressed and arguments employed herein do not necessarily reflect the official views of the Organisation or of the governments of its member countries.

Earlier versions of this paper were discussed at the Working Party No. 1 of the OECD Economic Policy Committee, the OECD Economic Policy Committee, the OECD Committee on Financial Markets and seminars of the New Approaches to Economic Challenges initiative and the OECD Economic Development and Review Committee. The authors would like to thank the participants for their feedback. They are also indebted to Christian Kastrop, Catherine L. Mann, Pier Carlo Padoan and Jean-Luc Schneider for their guidance and to Dan Andrews, Sonia Araujo, Geoff Barnard, Piet Battiau, Sebastian Barnes, Adrian Blundell-Wignall, Andreas Botsch, Romain Bouis, Alexandre Cazenave-Lacroutz, Federico Cingano, Sean Dougherty, Alberto Gonzalez Pandiella, Jonathan Greenhill, Stéphanie Guichard, Jørgen Elmeskov, Michael Förster, Pierre Leblanc, Catherine L. Mann, Pierre Poret, Francesca Romagnoli, Nicolas Ruiz, Sebastian Schich, Alain de Serres, Stéphane Sorbe, Jan Strasky, Douglas Sutherland, Dave Turner, Gert Wehinger, Andreas Wörgötter, Eckhard Wurzel and Naomitsu Yashiro for their comments. The authors are much obliged to Peter van de Ven for his insights about financial sector value added in national accounts and Maxime Ladaique, Pascal Marianna, Colin Webb and Bo Werth for providing them access to inequality, micro-level and industry data. They also thank Matthieu Segol for his quantitative analysis underlying Box 1 as well as Chantal Nicqt, Alexandre Cazenave-Lacroutz and Celia Rutkoski for excellent statistical and editorial assistance.

More detailed information is available from the following:

Cournède, B. and O. Denk (2015), "Finance and Economic Growth in OECD and G20 Countries", OECD Economics Department Working Papers, No. 1223, OECD Publishing.

Denk, O. and B. Cournède (2015), "Finance and Income Inequality in OECD Countries", OECD Economics Department Working Papers, No. 1224, OECD Publishing.

Denk, O. (2015), "Financial Sector Pay and Labour Income Inequality: Evidence from Europe", OECD Economics Department Working Papers, No. 1225, OECD Publishing.

Denk, O. and A. Cazenave-Lacroutz (2015), "Household Finance and Income Inequality in the Euro Area", OECD Economics Department Working Papers, No. 1226, OECD Publishing.

Series: OECD Economic Policy Papers

ISSN 2226583X

This document and any map included herein are without prejudice to the status of or sovereignty over any territory, to the delimitation of international frontiers and boundaries and to the name of any territory, city or area.

The statistical data for Israel are supplied by and under the responsibility of the relevant Israeli authorities. The use of such data by the OECD is without prejudice to the status of the Golan Heights, East Jerusalem and Israeli settlements in the West Bank under the terms of international law.

\section{(C) OECD 2015}

You can copy, download or print OECD content for your own use, and you can include excerpts from OECD publications, databases and multimedia products in your own documents, presentations, blogs, websites and teaching materials, provided that suitable acknowledgment of OECD as source and copyright owner is given. All requests for public or commercial use and translation rights should be submitted to rights@oecd.org. Requests for permission to photocopy portions of this material for public or commercial use shall be addressed directly to the Copyright Clearance Center (CCC) at info@copyright.com or the Centre français d'exploitation du droit de copie (CFC) at contact@cfcopies.com. 


\section{TABLE OF CONTENTS}

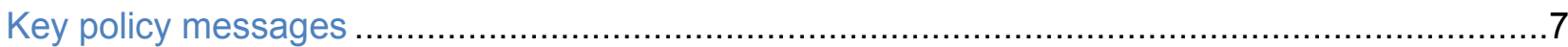

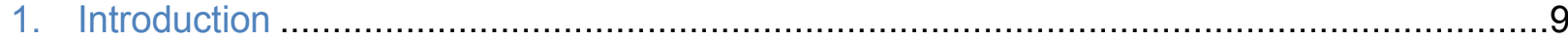

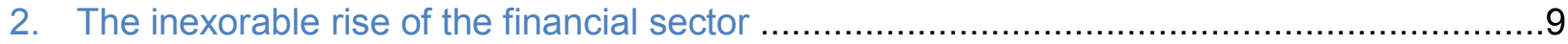

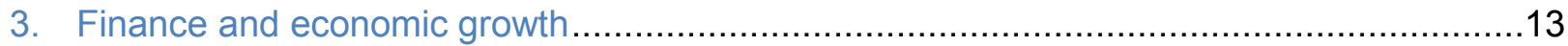

3.1. Possible transmission channels from the financial sector to growth.......................13

3.2. New aggregate evidence for OECD and G20 countries....................................15

3.3. Robustness of the estimated finance-growth link ...........................................

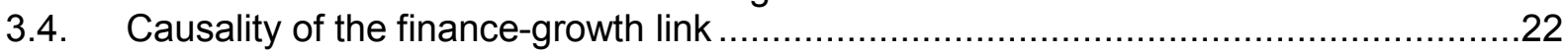

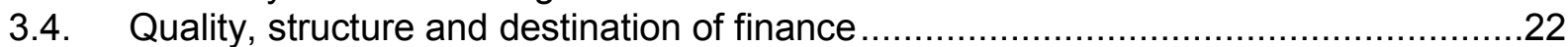

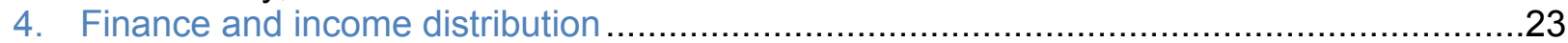

4.1. Possible transmission channels from finance to income inequality ........................23

4.2. New aggregate evidence on finance and income inequality in OECD countries ........28

4.3. Implications of financial expansion across the income distribution...........................31

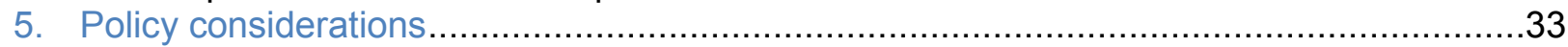

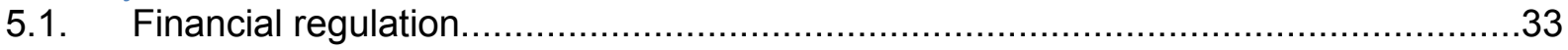

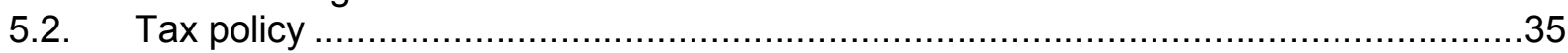

5.3. Financial reforms: win-win, income-enhancing and opposite effects

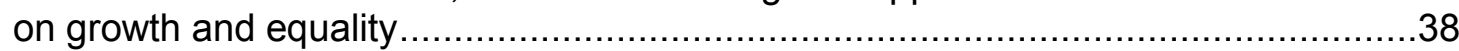

Appendix 1. Measuring financial sector value added: Broad principles and limitations...............39

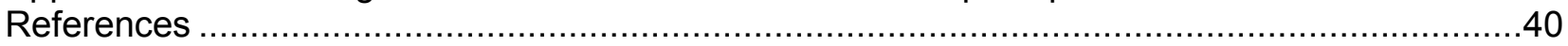

Boxes

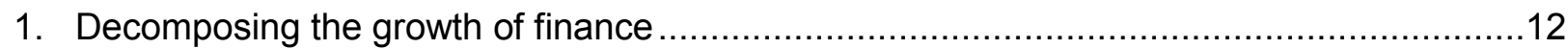

2. A brief summary of the empirical approach ............................................................ 19

3. Possible ways of ensuring greater VAT neutrality across different financial services .........37 


\section{Abstract \\ Finance and Inclusive Growth}

Finance is a vital ingredient for economic growth, but there can also be too much of it. This study investigates what fifty years of data for OECD countries have to say about the role of the financial sector for economic growth and income inequality and draws policy implications. Over the past fifty years, credit by banks and other intermediaries to households and businesses has grown three times as fast as economic activity. In most OECD countries, further expansion is likely to slow rather than boost growth. The composition of finance matters for growth. More credit to the private sector slows growth in most OECD countries, but more stock market financing boosts growth. Credit is a stronger drag on growth when it goes to households rather than businesses. Financial expansion fuels greater income inequality because higher income people can benefit more from the greater availability of credit and because the sector pays high wages. Higher income people can and do borrow more, so that they can gain more than others from the investment opportunities that they identify. The financial sector pays wages which are above what employees with similar profiles earn in the rest of the economy. This premium is particularly large for top income earners. There is no trade-off between financial reform, growth and income equality in the long term. In the short term, measures to avoid accumulating too much credit can, however, restrain growth temporarily. A healthy contribution of the financial sector to inclusive growth requires strong capital buffers, measures to reduce explicit and implicit subsidies to toobig-to-fail financial institutions and tax reforms to promote neutrality between debt and equity financing

JEL classification: D14; D63; G1; G2; G3; J16; J24; J31; O41; O47; O57.

Keywords: Finance; GDP growth, economic growth, OECD countries, G20 countries, financial regulation, too-big-tofail guarantees, debt finance, equity finance, household credit, business credit, bank credit, capital-market credit, stock market, income inequality; Gini coefficient, wage premium, wage differential

\section{Résumé}

\section{Finance et croissance inclusive}

La finance est un élément vital pour la croissance économique, mais il arrive aussi qu'il y ait trop de finance. Cette étude analyse ce que les données recueillies pendant un demi-siècle sur les pays de l'OCDE ont à nous dire sur le rôle du secteur financier pour la croissance économique et les inégalités de revenu et en tire les conséquences pour l'action publique. Au cours de ce dernier demi-siècle, les prêts des banques et autres intermédiaires aux ménages et aux entreprises ont augmenté trois fois plus vite que l'activité économique. Dans la plupart des pays de l'OCDE, de nouvelles expansions du crédit risqueraient d'affaiblir plutôt que de soutenir la croissance. Ce qui importe pour celleci, c'est la composition de la finance. L'expansion du crédit au secteur privé freine la croissance dans la majorité des pays de l'OCDE, mais le financement par les marchés boursiers est source de croissance. Le crédit pèse davantage sur celle-ci lorsqu'il profite aux ménages plus qu'aux entreprises. Le développement du secteur financier alimente les inégalités de revenu car les plus hauts revenus peuvent davantage tirer profit d'une offre de crédit plus abondante, mais également parce que les rémunérations versées dans le secteur de la finance sont supérieures. Les plus hauts revenus ont les moyens d'emprunter davantage et le font, de sorte qu'ils peuvent gagner plus que d'autres sur les possibilités d'investissement qu'ils identifient. Le secteur de la finance verse des rémunérations supérieures à celles des salariés des autres secteurs de l'économie à profil équivalent. Cet avantage est particulièrement marqué chez les plus hauts revenus. À long terme, aucun arbitrage n'est possible entre réforme financière, croissance et inégalités de revenu. À court terme cependant, les mesures visant à éviter un excès de crédit peuvent freiner temporairement la croissance. Une saine contribution du secteur financier à la croissance inclusive nécessite de solides volants de fonds propres, une réduction des subventions déclarées et implicites aux établissements financiers d'importance systémique et des réformes fiscales favorisant la neutralité entre financement par l'emprunt et financement sur fonds propres

Classification JEL : D14 ; D63 ; G1 ; G2 ; G3 ; J16 ; J24 ; J31 ; O41 ; O47 ; O57

Mots-clés : finance, croissance du PIB, croissance économique, pays de l'OCDE, pays du G20, réglementation financière, garanties des pouvoirs publics sur les établissements systémiques, financement par l'emprunt, financement sur fonds propres, crédit aux ménages, crédit aux entreprises, crédit bancaire, financement sur les marchés financiers, marché boursier, inégalités de revenu, coefficient de Gini, avantage de salaire, écarts de rémunération 


\section{Finance and Inclusive Growth}

\section{Key policy messages}

- Since the 1970s, the financial sector has expanded massively in many OECD countries. On average across the OECD, banks and similar institutions are now providing more than three times as much private-sector credit relative to GDP as half a century ago. Stock market capitalisation has tripled relative to GDP over the past forty years.

- Despite these fundamental trends, flows of new borrowing and lending remain low in parts of the OECD area as a legacy of the crisis.

- The financial crisis has raised deep questions about the role of the financial sector and its impact on growth and income distribution. The crisis has also stimulated reforms to help the sector contribute to growth that is strong, sustainable and inclusive.

- The empirical evidence in this study underlines that the financial sector is an important ingredient of growth. Economies gain a lot from moving from a small financial sector to a more developed one.

- However, there can be too much finance. When the financial sector is well developed, as has been the case in OECD economies for some time, further increases in its size usually slow longterm growth. Prior OECD studies concluded that excesses in credit extension also make economies more vulnerable to crises.

- These empirical results are obtained after adjusting for many possible growth drivers, including permanent institutional and other country specificities, trends and investment. They are also very robust to a large number of tests investigating, for example, the role of business cycle fluctuations, financial crises and endogeneity concerns.

- The composition of finance matters for long-term growth. Increases in credit to households have a more negative association with growth than credit to businesses. Bank-lending expansion is more negatively correlated with growth than increases in capital-market credit. Expansion in stock market funding is generally good for growth, but too much of it harms long-term growth. All these results hold on average across OECD countries: the situation of individual countries can be different, and the study provides examples of that.

- The data also show that economic inequalities widen when finance expands:

- The high level of pay in the financial sector is an important factor behind this link and has fuelled public questioning about the role of the financial sector. Evidence provided in this study shows that the financial sector generally pays its employees more than what workers with similar profiles get elsewhere. This premium increases more than proportionately with remuneration levels and becomes very large at the top. Moreover, male financial sector workers earn a substantial wage premium over female financial sector workers, especially at the top. 
- The distribution of credit can be an additional source of income dispersion if it implies that low income people cannot finance the opportunities they identify to the same extent as their better-off counterparts. The data indicate that, even relative to disposable income, low income households do not have as much credit as higher income households. Low income households' more restricted access to credit may however also reflect their higher risk, suggesting the presence of a trade-off between stability and equality.

- The empirical analysis documents a link from financial deregulation, measured by an aggregate indicator, to credit expansion and slower growth. It did not investigate the direct effects of each financial policy item on growth and inequality for lack of data covering enough countries item by item for long enough. Individual policies are discussed below based on their effects on financial outcomes and the above empirical evidence about how these financial outcomes influence growth and inequality.

- A healthy future for finance involves (1) avoiding credit overexpansion and (2) favouring a good composition of finance:

1. Avoiding credit overexpansion:

- Strong capital buffers help keep banking sound and reduce the degree to which governments need to stand by banks in trouble, because they make sure that owners remain responsible for losses. Substantial progress has been made already under the Basel III framework, but much remains to be done in particular to reduce governments' support for too-big-to-fail banks. ${ }^{1}$ The links between too much bank credit and slower growth, which are stronger where too-big-to-fail banks get more public support, underline the growth benefits of completing reform in this area.

- One way of ending too-big-to-fail would be to break up financial institutions into sufficiently smaller entities. Alternatively, reforms can focus on separating the utility functions of too-big-to-fail banks from their more risky activities and on requiring large institutions to set up credible resolution plans, so that they can be closed orderly if they fail the test of the market place.

- Future financial supervision should take a more high-level approach. In the past, supervisors did much to ensure that every financial institution complied with a set of rules. In the future, their key task will be to monitor system-level risks and take remedial action based on them. In particular, the link of more credit intermediation with slower and more unequal income growth highlights the benefits of using macroprudential measures such as debt service-to-income ratios to curb credit booms. The long-term benefits for income equality that can be expected from such macro-prudential measures have to be kept in mind when considering that, in the short term, they may make access to credit and property more difficult for low or middle income earners.

- Compensation reform can help to encourage decision-taking practices that take better account of possible long-term consequences. The large wage premia identified by the empirical analysis, especially at the top, suggests that such reforms can leave the financial sector attractive even if they result in lower pay levels. General efforts to improve gender pay equality would benefit the financial sector, where the gender pay gap is substantial, especially at the top.

1. For the sake of brevity, financial institutions that are too big or interconnected to fail, also sometimes referred to as systemically important financial institutions are simply called "too-big-to-fail" in the rest of the document. 
2. Favouring a better structure of finance:

- Tax reform is important to move towards a more healthy financial structure in the future. At the moment, most OECD countries have tax systems that encourage corporate funding through loans rather than equity. This so-called debt bias means that firms overall have too much debt and not enough equity. This generates instability, reduces growth, and compromises investments for the future. Reforms to make the choice between debt and equity more tax-neutral will support long-term growth.

- A healthy contribution of finance to growth also requires a review of housing policy. Many policies that help people buy a home have fuelled mortgage credit accumulation. There is scope for reform to make sure that tax provisions and regulations treat all kinds of lending on an equal footing, without encouraging the concentration of loans in housing.

- Extending value-added taxation to deposit-taking and lending would avoid favouring households over businesses in bank lending activities. Empirical evidence provided in this study suggests that a shift in lending from households to businesses should be growth-friendly.

- Financial reforms addressing well-identified government or market failures do not result in tradeoffs with long-term growth or inequality. However, measures to keep finance sound can hurt short-term activity and temporarily restrict access to credit and home ownership for some, until prices adjust.

- The crisis has highlighted the need for financial reform, but this need goes beyond the crisis, as the empirical relationships between finance and growth discussed above were present already before the crisis. Structural reform encouraging better finance would not only reduce the risk and cost of crises but also promote stronger, more inclusive growth.

\section{Introduction}

The global financial crisis, with its large adverse economic and social impact, has raised questions about the influence of the financial sector on economic activity and the distribution of income. This study investigates this influence to support reforms which can make the financial sector function better, thus contributing to stronger and more inclusive growth. The macroeconomic perspective taken by this report complements and supports the detailed financial-reform agenda set out in OECD (2014a).

This report presents the main findings from investigations into the influence of financial sector trends (Section 2) on growth (Section 3) and the distribution of income (Section 4) and then discusses the policy implications (Section 5). A set of working papers presents the underlying analysis in detail: Cournède and Denk (2015) investigate how the financial sector influences economic growth; Denk et al. (2015) focus on the economic effects of implicit bank debt guarantees; Denk and Cournède (2015) look at aggregate links between finance and income inequality; Denk (2015) analyses European micro-level data to probe the impact of financial sector pay on income inequality; Denk and Cazenave-Lacroutz (2015) document linkages between credit distribution across households and income inequality.

\section{The inexorable rise of the financial sector}

OECD countries have experienced a strong trend increase in the value-added share of the financial sector over the past half-century (Figure 1, Panel A). Profits have been the main source of the rising share of finance in GDP over the last four decades (Box 1). Labour compensation also contributed substantially, 
first through an increase in the share of the financial sector in total employment that occurred from 1970 to 1990 , and second through rising financial sector wages.

Using value added as an indicator of financial sector size has advantages, such as providing an aggregate measure for many different services. Financial sector value added covers banks, insurers and other financial auxiliaries, such as wealth managers. Banks and other lenders represent by far the largest component of the financial sector, accounting for two-thirds of its value added on average across OECD countries. Banks, insurers and financial auxiliaries have all expanded at broadly similar rates in most OECD countries when measuring them by national-accounts value added. The United States are one exception, where wealth management has expanded substantially (Greenwood and Scharfstein, 2013), as wealth has risen while the unit costs of finance have not fallen (Gennaioli et al., 2014).

Financial sector value added also involves limitations which warrant the use of alternative indicators. Measuring the value added of services that are remunerated indirectly, such as deposit-taking, lending and most insurance activities, is more complicated and requires modelling assumptions (Appendix 1). The limitations of the models imply that financial sector value added gives signals that have to be interpreted with caution. One example is that national-account value added does not include banks' net income from capital gains on securities that they trade or hold for their own account. The sharp rise of these activities in the last two decades means that the national accounts might underestimate the rise in financial sector value added (Bazot, 2014).

The analysis will therefore also use two direct measures of financial activity: the volume of credit provided by financial intermediaries to the non-financial private sector and stock market capitalisation. ${ }^{2}$ The volume of credit provided by banks and other financial institutions to non-financial firms and households, henceforth referred to as "intermediated credit", measures a key output that financial intermediaries generate for the real economy. Stock market capitalisation also provides a gauge of the important service that the financial sector provides by facilitating the equity funding of businesses. Similarly to the value added of finance, intermediated credit and stock market capitalisation have both been on upward trends:

- Credit by banks and other intermediaries has risen strongly in nearly all OECD countries since the 1960s, on average more than tripling relative to GDP (Figure 1, Panel B). Several financial crises during the 1990s interrupted the upward trend in the Nordic countries, Mexico and some Asian countries, though in most cases only briefly. Credit-to-GDP ratios have also come down since the onset of the global financial crisis as lending activity has shrunk and write-downs have been taken on past loans (Bouis et al., 2013). In many OECD countries, the growth in credit intermediation has outpaced the growth in financial sector value added. This difference relates to lower net interest margins, which may reflect possible increases in productivity as well as likely reductions in screening efforts and credit quality (Keys et al., 2010).

- The amount of stock market financing has expanded considerably in OECD countries over the past four decades (Figure 1, Panel C). The expansion has been accompanied by very large bubbles in Japan in the late 1980s and globally in the late 1990s.

2. Appendix 1 to Cournède and Denk (2015) describes the sources of the data used in Sections 2 and 3. 
Figure 1. Financial activity has considerably expanded over the past four decades A. Value added by the financial sector, $\%$ of GDP
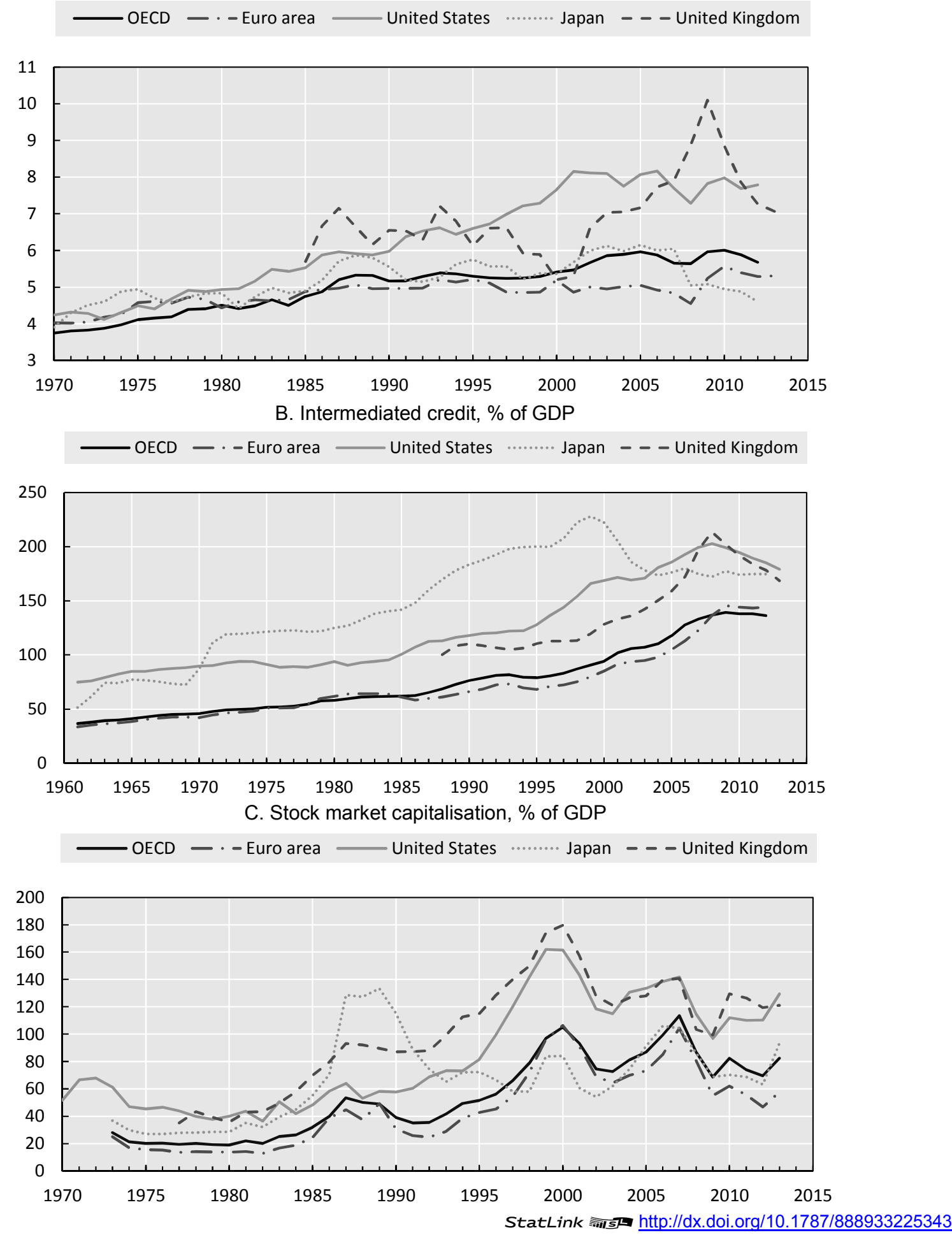

Note: Value added of finance includes banking, insurance and other financial activities. Intermediated credit refers to credit by deposit money banks and other financial institutions to the non-financial private sector. Stock market capitalisation is the value of all listed shares. OECD is the simple average of OECD countries for which data are available (20 to 22 depending on the panel). Euro area is the simple average of the OECD countries that belong to the euro area.

Source: OECD Structural Analysis database; OECD National Accounts; World Bank Global Financial Development database; BIS credit series; Thomson Reuters; OECD Secretariat calculations. 


\section{Box 1. Decomposing the growth of finance}

Financial sector value added remunerates capital and labour. Labour compensation can be further separated into employment and wages. The difference between gross value added and labour compensation, which approximates gross operating surplus, provides a measure of profits.

Rising profits have been the main source of the widespread increase in the share of financial sector value added in GDP over the last four decades (Figure 2). Profits have risen from 42 to $47 \%$ of financial sector value added over this period. Furthermore, the profit share is higher in finance than in the rest of the economy, where it stands at $36 \%$ of value added. The combination of these two factors implies that the rise of finance has contributed more than half a percentage point to the $4 \frac{1}{2}$ percentage point economy-wide increase in the profit share over the last four decades. The direct contribution of financial sector expansion to the rise in the profit share is therefore similar in size to the estimated effect of greater domestic and international competition but small compared with other drivers including the lower price of investment goods and capital-augmenting technological advances (OECD, 2012; Karabarbounis and Neiman, 2014).

Figure 2. Profits and employment explain most of the rise in the value-added share of finance Change in value added in \% of GDP, 1970-2010
Wage income per worker
Employment
Profits

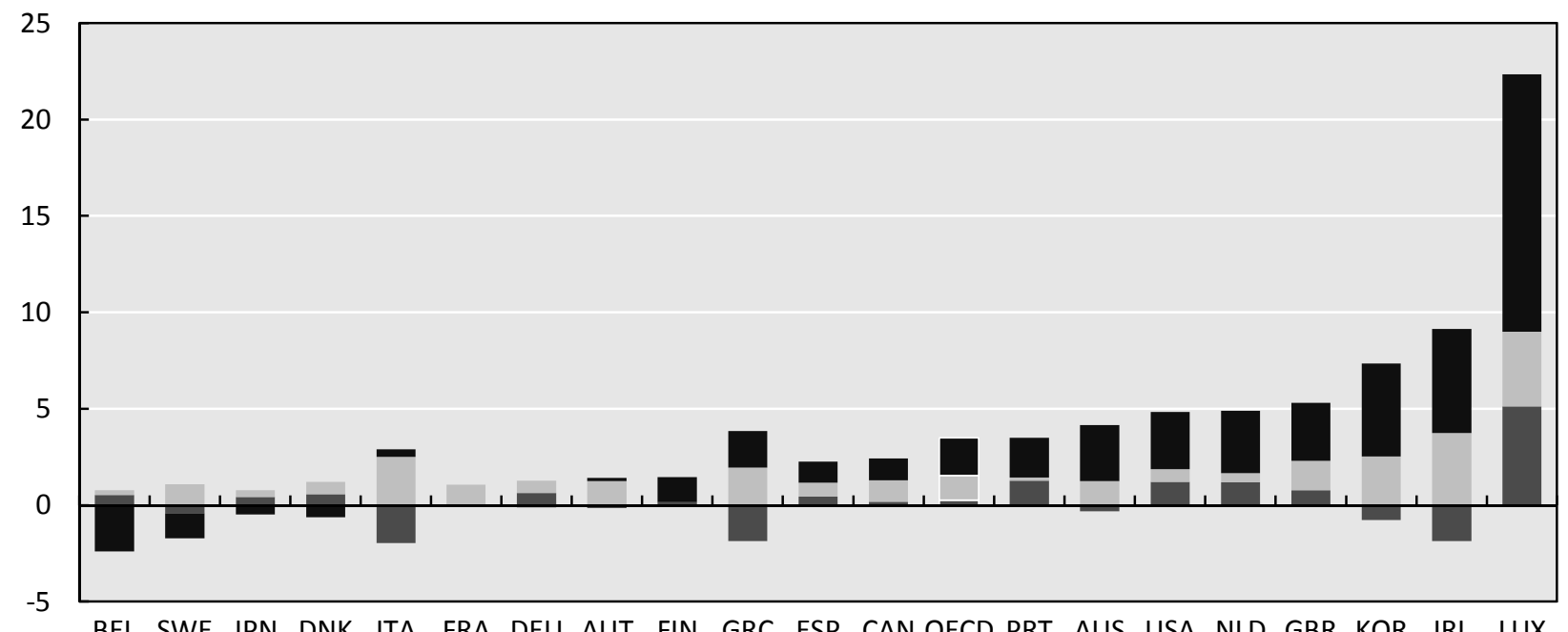

StatLink त्ञात http://dx.doi.org/10.1787/888933225356

Note: Profits are measured as the difference between gross value added and gross labour compensation (including taxes and social security contributions on labour income). OECD is the simple average of OECD countries for which data are available.

Source: EU-KLEMS database; OECD Secretariat calculations.

Rising labour compensation has also been an important reason why finance has expanded faster than the rest of the economy in most OECD countries. Imperfections in the measured split between labour and capital compensation may however result in underestimating pay growth. Indeed, some of the profits accrue to financial sector employees, when they generate capital gains on deferred stocks, a form of compensation that the sector uses particularly intensively (Cai et al., 2010).

The decomposition of labour compensation shows that employment contributed more than wages to the rising share of finance in GDP over the last four decades. Financial expansion generated much stronger employment creation in the sector than the rest of the economy until the second half of the 1980s (Figure 3). The financial sector share of total employment has been broadly flat since the early 1990s: profits and wages explain most of the subsequent rise in the financial sector share of GDP. 


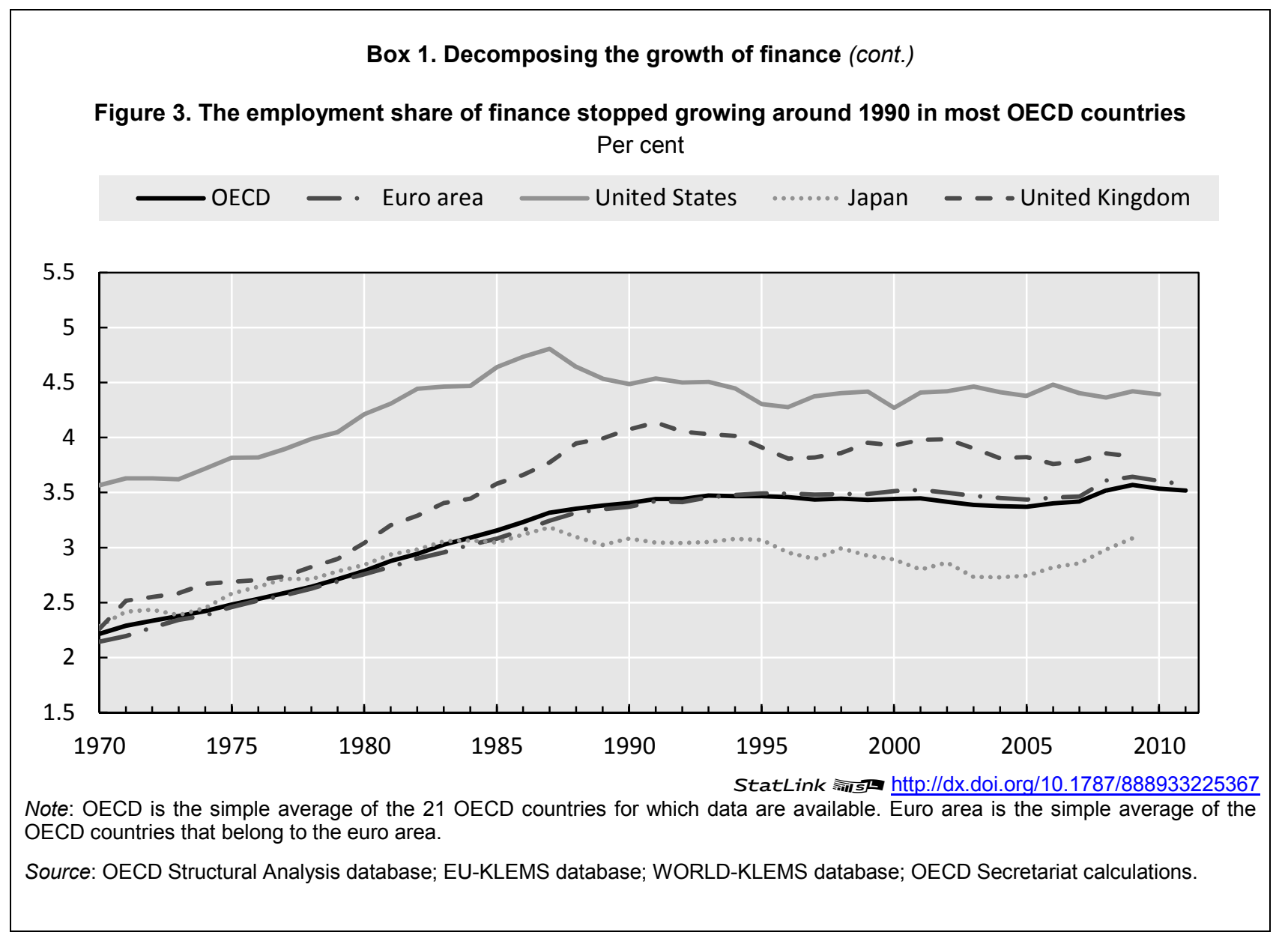

\section{Finance and economic growth}

This section looks at how finance influences economic growth. It first reviews potential transmission channels from finance to growth. The section then presents what the data for OECD and G20 countries say about the finance-growth nexus at different stages of financial development and about the direction of causality. It finally reports empirical evidence about how the quality and structure of finance shape its relationship with economic growth.

\subsection{Possible transmission channels from the financial sector to growth}

A wide-ranging economic literature has investigated the role of finance for growth. The present text does not present it in detail: Section 2.1 of Cournède and Denk (2015) provides an overview of this literature and Beck (2012) a more extensive survey. The focus here is on summarising important potential transmission channels.

On the positive side, greater financial development can be expected to fuel economic growth (Leahy et al., 2001; Levine, 2005) especially by:

- reducing the need to finance projects from own funds,

- allocating capital to more productive uses, 
- monitoring investments more professionally,

- facilitating international trade (Johansson et al., 2014),

- smoothing demand by individual firms and households, therefore reducing adjustment costs,

- providing more insurance, boosting innovation,

- facilitating the conduct of monetary policy by strengthening its transmission although sometimes at the cost of greater risks to financial stability (Cournède et al., 2008),

- generating large productivity gains within the financial sector that raise economy-wide productivity.

On the negative side, further expansion of an already large financial sector could slow economic growth in particular by:

- misallocating capital by funding projects with too low profitability, for instance when

- distortions exist in the tax system (Section 5.2 below);

- large implicit subsidies to too-big-to-fail banks create incentives to lend excessively (Schich and Aydin, 2014; Denk et al., 2015) or

- opacity about underlying credit risk misleads ultimate investors into funding too much lending (FCIC, 2011);

- magnifying the economic costs of

- inefficiencies in financial intermediation (Trew, 2008; Bazot, 2014);

- too-big-to-fail and other public guarantees (Admati and Hellwig, 2013) or

- financial sector wage premia, which increase with the size of credit intermediation (Cournède and Denk, 2015; Denk, 2015);

- drawing highly talented workers away from sectors with greater productive potential (Bolton et al., 2012; Cecchetti and Kharroubi, 2015; Kneer, 2013; Tobin, 1984);

- generating boom-and-bust financial cycles that slow long-term growth (Cerra and Saxena, 2008; Furceri and Mourougane, 2012; Ollivaud and Turner, 2014);

- increasing vulnerabilities to shocks and international financial contagion (Ahrend and Goujard, 2011; Sutherland et al., 2012; Mian and Sufi, 2014);

- heightening the risks of regulatory capture (Baxter, 2011);

- exacerbating income inequality (Jaumotte et al., 2013, and Section 4 below), which can itself hurt growth (Berg and Ostry, 2011; Causa et al., 2014; Cingano, 2014).

Existing investigations have produced evidence for both positive and negative channels: the direction of the net effect is thus an empirical question. Studies conducted until the early 2000 s on samples including developing countries typically found a positive link between more finance and higher growth (Goldsmith, 1969; King and Levine, 1993a, 1993b; Levine et al., 2000; Beck et al., 2000). Empirical analyses that focus more on developed economies or use more recent data yield more nuanced or different results. Previous work on OECD countries found that intermediated credit was positively linked with investment 
but negatively with growth (Bassanini et al., 2001). Recent empirical studies document that the positive finance-growth link identified by Levine et al. (2000) and Beck et al. (2000) vanishes when using more recent data (Rousseau and Wachtel, 2011; Arcand et al., 2012). Finally, investigations covering developing and advanced economies suggest that more finance is linked to higher growth at low levels of financial development, but that the link gradually becomes weaker as finance expands and turns negative when intermediated credit rises above 90\% of GDP (Arcand et al., 2012; Beck et al., 2014; Cecchetti and Kharroubi, 2012; Law and Singh, 2014; Sahay et al., 2015). These recent findings are in line with the theoretical insight that external finance is essential for economic development but that negative effects can kick in at the margin when the financial sector becomes too large. Questions remain regarding whether similar patterns connect financial expansion and economic growth in OECD countries, where countries stand in this relationship, and which types of financial activity influence growth most strongly.

\subsection{New aggregate evidence for $\mathrm{OECD}$ and $\mathrm{G} 20$ countries}

\section{The direction of the link varies with the size of finance}

The empirical evidence for OECD countries over the past five decades indicates that more finance is linked to sharply higher growth at low levels of financial development but that, above a certain point and at the margin, further financial expansion is associated with slower growth. This pattern can be observed when measuring financial activity through value added as estimated in the national accounts (Figure 4, Panel A). For instance, an increase in the value-added share of the financial sector by 1 percentage point from 4 to $5 \%$ is associated with an increase in GDP growth by about 0.2 percentage points, although the coefficient is surrounded by a large confidence interval and not statistically significant. However, the marginal effect becomes negative and statistically significant above 5\% of GDP.

More direct measures of financial activity show the same relationship with greater clarity. A rise in intermediated credit from 20 to $30 \%$ of GDP is associated with economic growth rising by more than a percentage point. This economically large effect is also statistically significant at the $10 \%$ level (Figure 4 , Panel B). However, this relationship quickly becomes much smaller and then negative, so that for instance an increase from 100 to $110 \%$ of GDP is linked to a 0.25 percentage point reduction in economic growth. A similar pattern holds for increases in stock market funding: when they occur from a low to moderate base, they are associated with marked increases in economic growth, but stock market expansion from a higher base brings lower additional benefits, and from a very high base, it is linked to slower growth (Figure 4, Panel C).

The thresholds describe the finance-growth link across OECD countries but do not provide an optimal size of finance with which to compare the situation in any given country. First, the thresholds represent cross-country averages. Each country's institutions and circumstances are bound to influence the points at which the incremental effects on growth of a bigger financial sector, more credit or larger stock markets turn negative. The data are sufficiently rich to identify average thresholds across countries but not rich enough to pin down specific thresholds by country. Second, the empirical methodology implies that much uncertainty surrounds the thresholds, even if they lie close to the results obtained by Arcand et al. (2012), Beck et al. (2014), Cecchetti and Kharroubi (2012) and Law and Singh (2014).

These results show that financial development is linked with much stronger growth at low levels of financial development but that, above a certain point, further expansion becomes associated with growth slowing down. As such, they raise two sorts of questions. First, what is the main effect of a small change in financial size when the entire dataset is considered: is it linked with higher or lower growth? Second, does some degree of causality run from changes in the size of finance to growth? The rest of the section addresses these two questions in turn. 
Figure 4. The estimated link between finance and growth varies with the size of finance

A. Estimated change in per capita GDP growth when financial sector value added expands by $1 \%$ of GDP

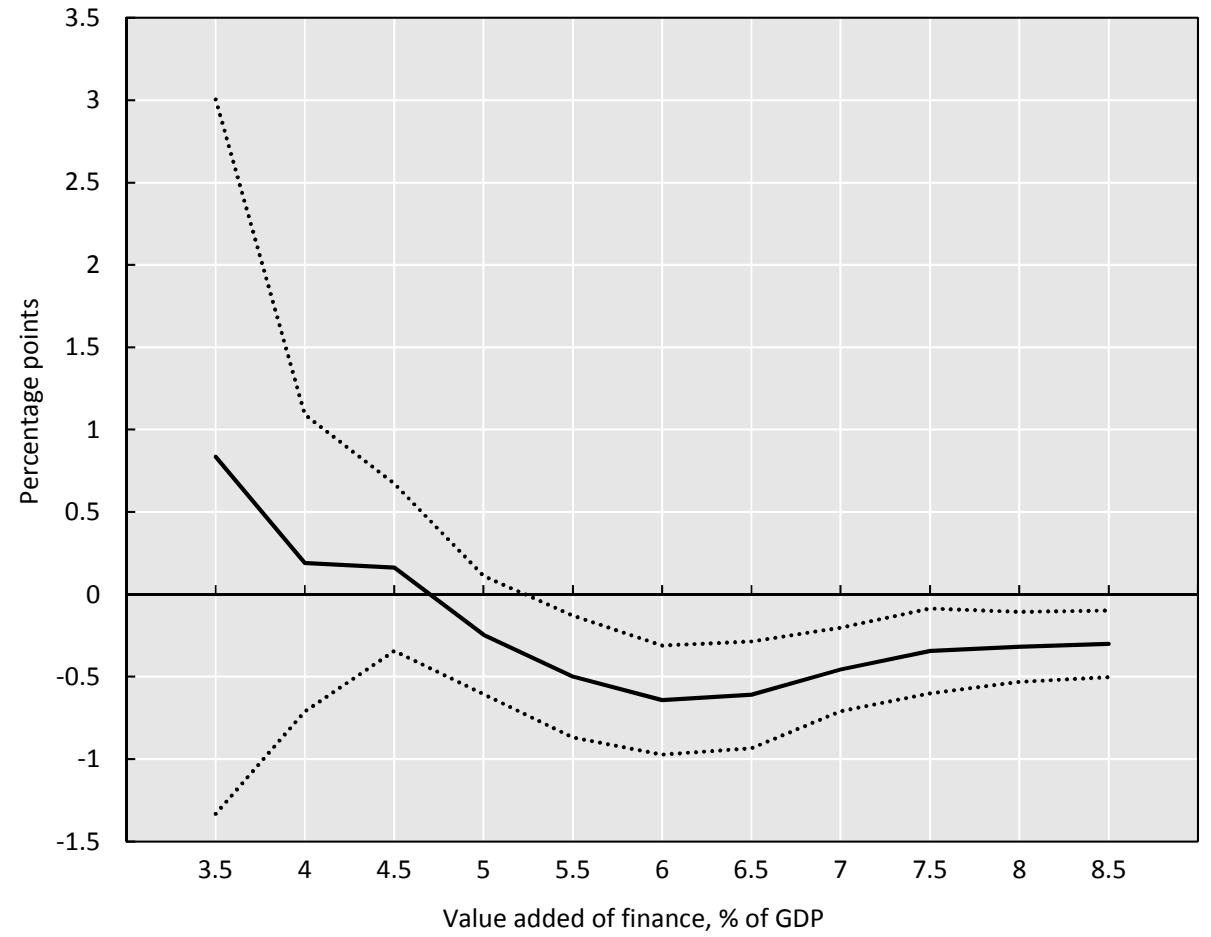

B. Estimated change in per capita GDP growth when credit intermediation increases by $10 \%$ of GDP

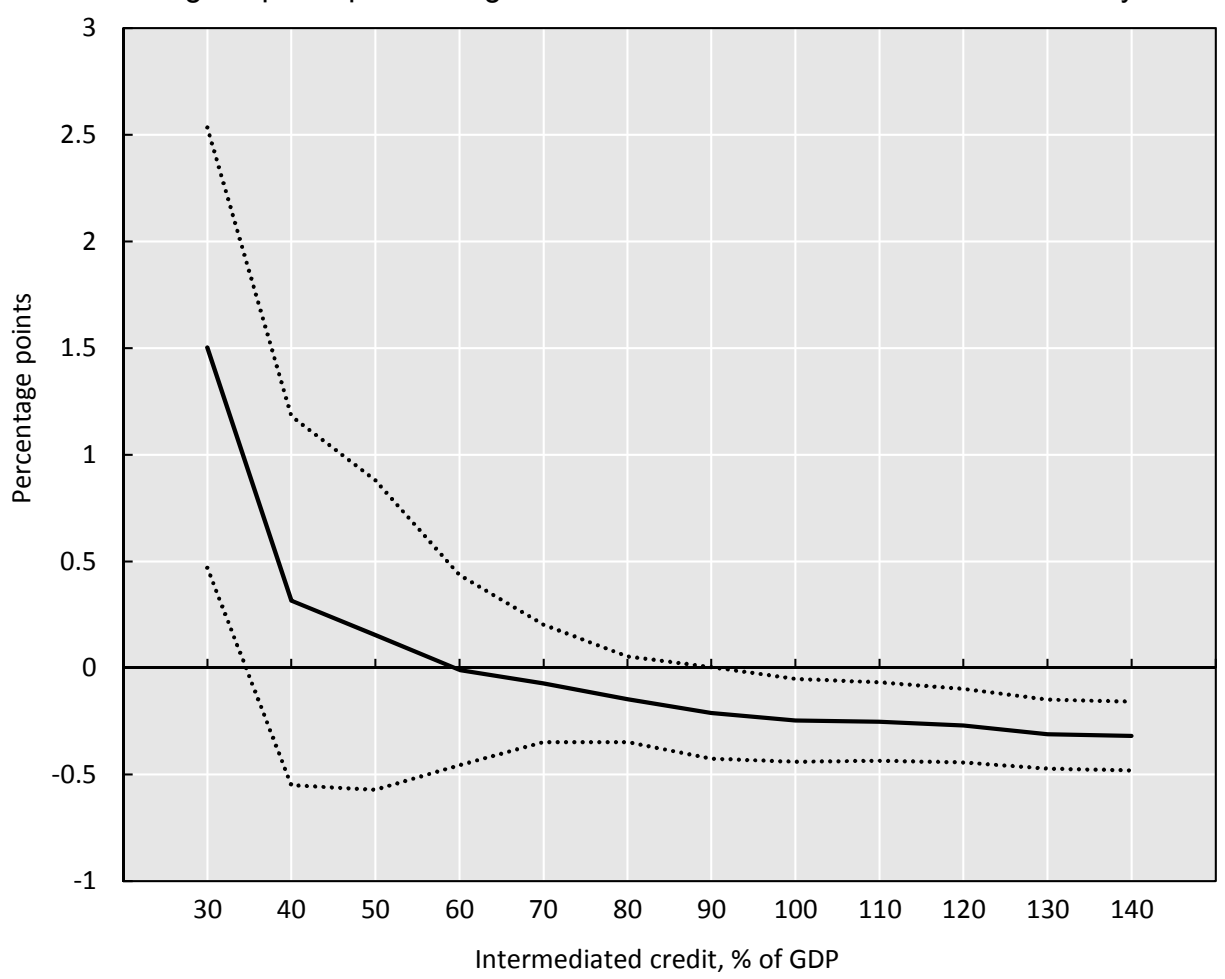


C. Estimated change in per capita GDP growth when stock markets expand by $10 \%$ of GDP

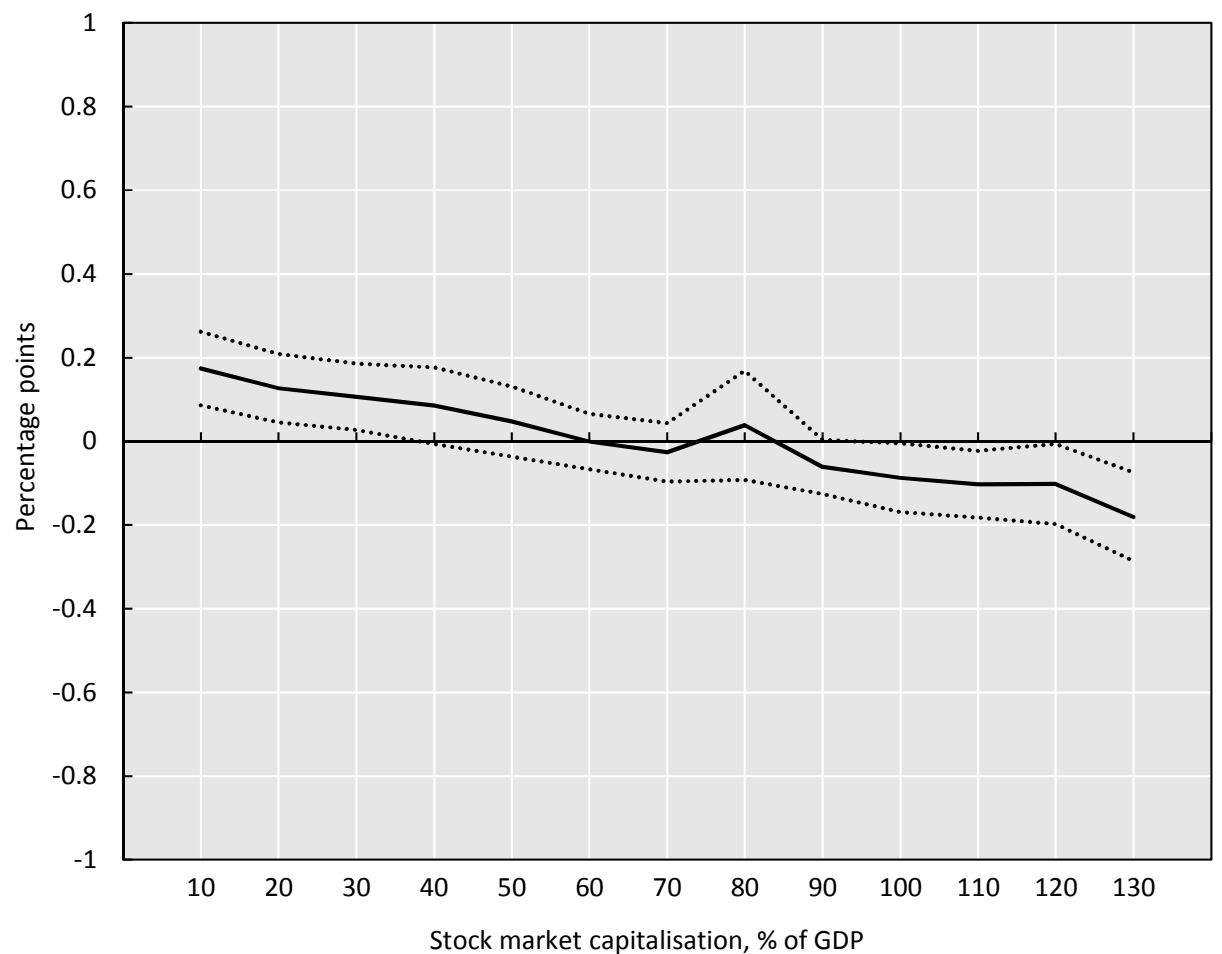

StatLink : -iाs http://dx.doi.org/10.1787/888933225375 Note: Value added of finance includes banking, insurance and other financial activities. Intermediated credit is credit to the nonfinancial private sector by financial institutions. Stock market capitalisation is the value of all shares listed in a stock market. The dotted lines represent the $90 \%$ confidence band. See Cournède and Denk (2015) for details. The samples comprise 32-34 OECD countries.

Source: OECD Secretariat calculations using OECD Structural Analysis database; World Bank Global Financial Development database; BIS credit series; Statistics Canada; World Bank World Development Indicators database; OECD Economic Outlook database; Barro, R. J. and J. W. Lee (2013), "A New Data Set of Educational Attainment in the World, 1950-2010", Journal of Development Economics, Vol. 104.

\section{The estimated growth effects of further financial expansion are negative for credit and positive for stocks}

Estimations based on the entire dataset for OECD countries show that, for the average country, an increase in financial sector value added or intermediated credit from their previous values is associated with slower growth (Figure 5). In contrast, stock market expansion is associated with higher growth (Figure 5). Extending the dataset to include the G20 countries yields the same findings that an increase in intermediated credit is associated with slower growth and a stock market expansion with higher growth. ${ }^{3}$ The results are symmetric: reductions in financial sector value added or intermediated credit are linked with higher growth, and stock market contractions with slower growth.

3. Statistical gaps preclude testing the role of financial sector value added in the extended dataset covering OECD and G20 countries. Cournède and Denk (2015) present the empirical approach in detail while Box 2 summarises it. 
Figure 5. Different forms of financial expansion have contrasting effects on growth at the margin Percentage point change in real GDP per capita growth

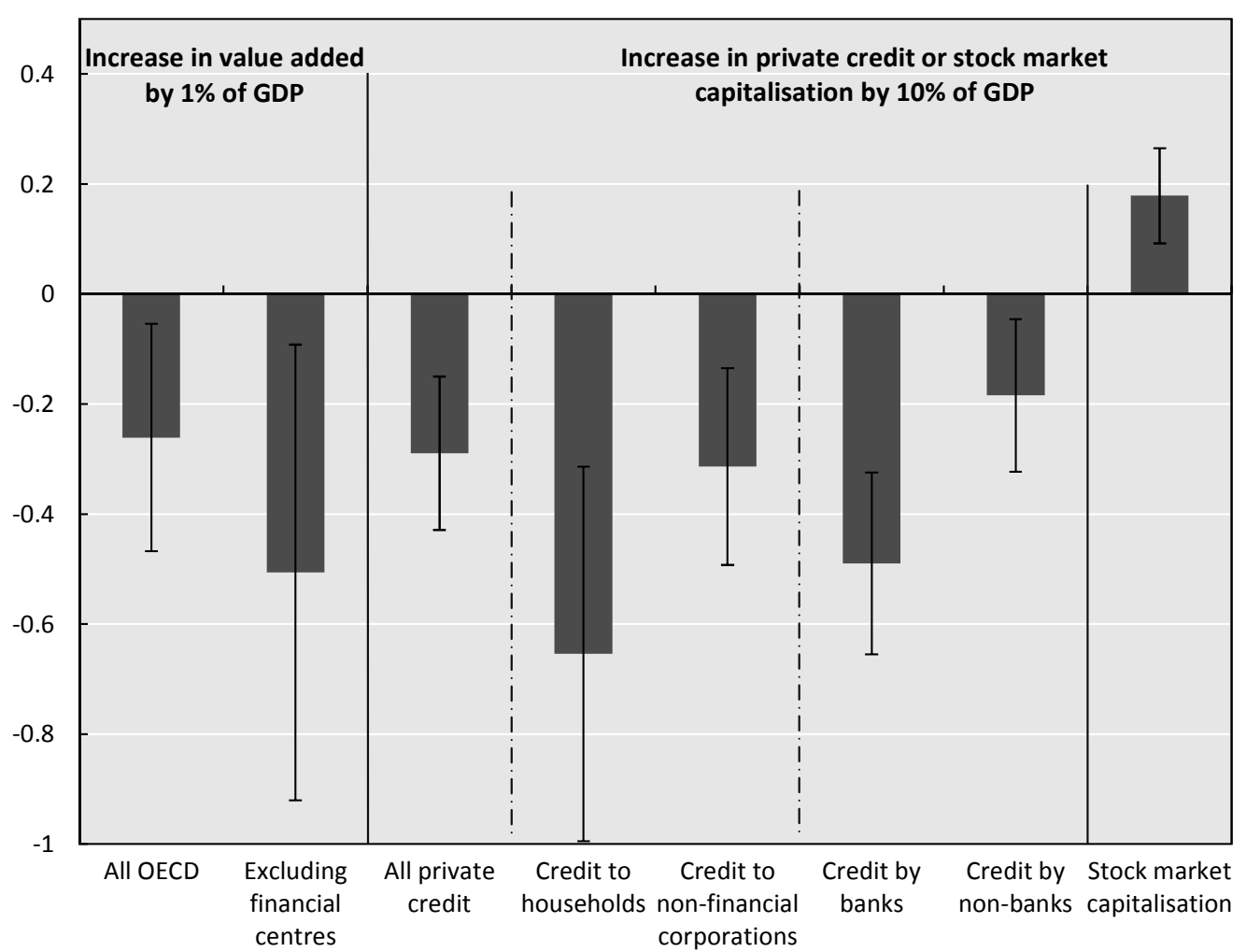

StatLink sils $\mathrm{http}: / / d x . d o i . o r g / 10.1787 / 888933225381$ Note: The figure shows point estimates surrounded by $90 \%$ confidence intervals. All private credit uses different data than the decompositions by borrower (Credit to households and to non-financial corporations) and by lender (Credit by banks and by nonbanks) and should therefore not be viewed as a weighted average.

Source: Cournède, B. and O. Denk (2015), "Finance and Economic Growth in OECD and G20 Countries", OECD Economics Department Working Papers, No. 1223, OECD Publishing, Paris.

\subsection{Robustness of the estimated finance-growth link}

The empirical approach, summarised in Box 2, identifies the link of finance with growth after adjusting for many possible growth drivers. Furthermore, the results are very robust to a large number of sensitivity tests.

\section{The links take into account many potential drivers of the relationship}

Permanent institutional and other country specificities

The estimated links hold after adjusting for time-invariant differences across countries. This correction adjusts for the effects of permanent cross-country differences. For instance, legal systems may influence the relationship. To pick another example, funded retirement-income systems can be expected to fuel larger financial systems than pay-as-you-go schemes, all other things being equal. 


\section{Box 2. A brief summary of the empirical approach}

The following baseline specification underlies the relationship between growth and finance after controlling for potential common sources of co-movement in the parameter of interest $\beta$ :

$$
\text { Growth }_{c t}=\beta \text { Fin }_{c t}+x_{c t} \gamma+\rho_{c}+\tau_{t}+\varphi_{c} t+\varepsilon_{c t}
$$

The dependent variable Growth $_{c t}$ is the annual percentage growth rate of real GDP per capita in country $c$ and year $t$. The indicator Fin $_{c t}$ measures financial sector value added, intermediated credit or stock market capitalisation. The vector of variables $x_{c t}$ includes standard growth determinants identified by the literature (Mankiw et al., 1992; Caselli et al., 1996; Arnold et al., 2011): investment, human capital (approximated by years of schooling) and workingage population growth. The regressions account for country-specific constant drivers of GDP growth $\rho_{c}$ and for common shocks $\tau_{t}$. The specification also includes country-specific time trends $\varphi_{c} t$ which absorb the effect of the downward trend in GDP growth and upward trend in financial indicators that many OECD countries have experienced. The regressions underpinning Figure 4 use the same specifications and controls (with the exception of the countryspecific time trends as above-trend indebtedness is unlikely to be conducive to higher growth even at low levels of finance).

Source: Cournède and Denk (2015) present the econometric methodology and data sources in detail.

Trends

The links are established when controlling for country-by-country time trends. This adjustment means that the negative finance-growth link identified for financial sector value added and intermediated credit goes beyond the mere observation that growth trended down and finance up over the past half-century. This adjustment also ensures that convergence effects do not bias the estimates.

Standard growth drivers

The links are established after controlling for standard growth drivers identified by the economic literature. The specification includes growth determinants commonly used in empirical studies, which arise naturally in a model of growth involving human capital: investment, years of schooling and working-age population growth.

\section{The results are robust to a wide range of sensitivity checks}

Possible additional growth drivers

The estimated links remain the same if controlling for other factors that may influence growth. Such additional checks have been conducted for the size of government, the share of household consumption in GDP, openness to trade, and innovation measured by patents and research and development spending.

\section{Investment}

The baseline specification controls for the growth impact of investment. Including this source of growth reduces the scope for omitted-variable bias but takes out the effect of finance on growth through funding investment. However, re-estimating the baseline specification without controlling for investment does not alter the results. This means in particular that the link, at the margin, between more intermediated credit and slower growth remains even after allowing for the investment-enhancing role of credit. 
The business cycle

Fourth, the results are robust to adjusting for the cycle. Substituting potential for actual growth uncovers relationships of the same sign, with similar statistical significance, though the size of the coefficients is smaller. Similarly, size and statistical significance of the coefficients are not very different when five-year averages are used instead of annual data. These findings imply that the business cycle is not driving the results. In particular, these checks indicate that the positive association between stock markets and growth goes beyond the demand effects generated by share-price movements.

\section{Financial crises}

The estimated links remain significant and have the same signs and broadly the same size if abstracting from the global financial crisis and even from all banking crises catalogued by Laeven and Valencia (2012). The coefficient of intermediated credit falls by a third, and the other coefficients are essentially unchanged, when removing all crises. These results indicate that the estimated relationships between finance and growth go deeper than the impact of the crisis, or all financial crises, on growth.

Capital share

The results are robust to controlling for the capital share of total income. This check addresses the concern that the negative link between credit and growth might simply be capturing that growth slows down after a lot of capital is accumulated. However, the results rule out such a phenomenon: they are unchanged when controlling for the capital stock and the capital stock itself boosts long-term growth. The capital share is not included in the baseline regression to avoid reducing the sample size substantially.

\section{Differences between countries}

The links exhibit broadly the same signs across countries (Table 1). The negative sign of the marginal link between intermediated credit and growth remains significant in 26 out of the 42 OECD and G20 countries. This is strong proof of robustness since allowing for variation across countries seriously reduces the identification power of the econometric estimation. Chile, India, South Africa and Turkey are the only countries where the estimated link is significantly positive. This result is consistent with the view that finance is an engine of growth at earlier stages of economic development. The positive links for this group of countries are estimated to hold on average over the full period for which data are available, which leaves open the possibility that strong credit increases in recent years may threaten growth, a risk that appears relevant in Turkey (OECD, 2014b). 
Table 1. The finance and growth relationship shows limited variation across OECD and G20 countries

\begin{tabular}{|c|c|c|c|}
\hline Measure of finance: & $\begin{array}{c}\text { Value added of } \\
\text { finance } \\
\text { (1) }\end{array}$ & $\begin{array}{c}\text { Intermediated } \\
\text { credit } \\
\text { (2) }\end{array}$ & $\begin{array}{c}\text { Stock market } \\
\text { capitalisation } \\
\text { (3) }\end{array}$ \\
\hline Argentina & . & -- & -- \\
\hline Australia & - & - & -- \\
\hline Austria & -- & + & ++ \\
\hline Belgium & - & - & + \\
\hline Brazil & . & + & ++ \\
\hline Canada & ++ & -- & ++ \\
\hline Chile & + & ++ & - \\
\hline China & . & -- & ++ \\
\hline Czech Republic & - & -- & ++ \\
\hline Denmark & - & -- & + \\
\hline Estonia & -- & -- & ++ \\
\hline Finland & - & -- & ++ \\
\hline France & + & - & + \\
\hline Germany & -- & - & + \\
\hline Greece & -- & -- & ++ \\
\hline Hungary & -- & -- & + \\
\hline Iceland & - & + & + \\
\hline India & . & ++ & - \\
\hline Indonesia & . & -- & -- \\
\hline Ireland & -- & -- & - \\
\hline Israel & . & -- & ++ \\
\hline Italy & - & -- & + \\
\hline Japan & + & -- & ++ \\
\hline Korea & -- & - & ++ \\
\hline Luxembourg & -- & -- & ++ \\
\hline Mexico & -- & - & + \\
\hline Netherlands & -- & - & + \\
\hline New Zealand & -- & - & ++ \\
\hline Norway & -- & -- & -- \\
\hline Poland & -- & -- & + \\
\hline Portugal & ++ & -- & ++ \\
\hline Russian Federation & . & -- & ++ \\
\hline Saudi Arabia & . & -- & ++ \\
\hline Slovak Republic & ++ & -- & ++ \\
\hline Slovenia & -- & -- & ++ \\
\hline South Africa & . & ++ & - \\
\hline Spain & ++ & -- & + \\
\hline Sweden & -- & -- & ++ \\
\hline Switzerland & + & -- & ++ \\
\hline Turkey & . & ++ & -- \\
\hline United Kingdom & - & -- & ++ \\
\hline United States & - & - & + \\
\hline
\end{tabular}

Note: Entries indicate the sign of the coefficient in a regression of GDP growth per capita on the measure of finance. One plus sign indicates no significance at the $10 \%$ level; two plus or minus signs (++/--) denote significance at the $10 \%$ level; a full stop means that no observation is available. The specification, control variables and sample are the same as in Figure 5 . In each case, the measure of finance is interacted with a set of country fixed effects to allow for cross-country heterogeneity in the finance and growth relationship.

Source: Cournède, B. and O. Denk (2015), "Finance and Economic Growth in OECD and G20 Countries", OECD Economics Department Working Papers, No. 1223, OECD Publishing, Paris. 


\subsection{Causality of the finance-growth link}

Causality appears to be running from more intermediated credit to slower growth and from larger stock markets to higher growth. The standard approach for testing causality in growth regressions (system generalised method of moments applied to five-year averages) detects that more credit by banks and other intermediaries slows growth (see Section 5 of Cournède and Denk, 2015).

A more thorough investigation employing a novel empirical approach also identifies a causal link from more intermediated credit to slower growth and from larger stock markets to stronger growth. This approach uses IMF indicators of financial deregulation to trace expansions in financial activity that are not themselves driven by growth. In technical terms, the IMF indicators, built by Abiad et al. (2010), serve as instruments to identify exogenous variation in financial activity, and their effect is allowed to vary over time to differentiate between different phases of deregulation (see Section 5 of Cournède and Denk, 2015). The data indicate that changes in growth, the business cycle position and the occurrence of banking crises do not generally influence the IMF financial regulation indicator. These facts make the regulation indicator a very useful tool to identify the effect of finance on growth while abstracting from the impact of growth on financial sector size. The analysis finds that financial deregulation has significantly contributed to financial sector expansion, measured by value added or intermediated credit, especially in the past two decades.

The causality investigation also provides evidence that the link between stock markets and growth is robustly estimated. One hypothetical concern regarding the estimated link is that it might capture that the expectation of stronger growth boosts stock market valuations, creating a positive association between stock market size and growth. However, the relationship between stock market size and growth remains significant and positive when using the IMF financial regulation indicator to instrument stock market size. This result means that the positive association between stock market size and growth arises from a deeper connection than the simple link between share price fluctuations and growth expectations.

The results about causality hold when abstracting from banking crises, indicating that they are not simply the result of financial deregulation being followed by financial crashes. Furthermore, the causality results hold for the OECD sample as well as for the extended one including other G20 countries. The same investigation finds no evidence of a causal link when measuring financial sector size with value added.

These economy-wide results about a causal link from more intermediated credit to lower aggregate growth are consistent with recent sector-level evidence for OECD countries. Pagano and Pica (2012) reassessed Rajan and Zingales' (1998) estimate that, in a dataset including many developing countries, more finance is associated with stronger value-added growth of financially dependent sectors. Their reassessment uncovered that the effect of financial expansion on the value-added growth of financially dependent sectors turns from positive to negative, though not statistically significant, when restricting the sample to OECD countries. The present study complements Pagano and Pica's (2012) result by indicating that, when looking at economy-wide impacts, the negative effect of more intermediated credit is statistically significant in OECD countries.

\subsection{Quality, structure and destination of finance}

The quality of financial intermediation has an effect on growth. Unsurprisingly, a better quality of credit intermediation, proxied by a lower incidence of non-performing loans (NPL), is linked with higher growth. More credit remains associated with slower growth when controlling for the effect of lower quality measured by a higher NPL share (see Cournède and Denk, 2015). In other words, the link, at the margin, from more credit to slower growth goes beyond the impact of accumulating more non-performing loans. The quality of the regulatory framework is likely to shape the consequences of financial expansion. For instance, Hermes and Meesters (2015) argue that financial liberalisation appears to enhance bank efficiency in countries with sound banking regulation but to reduce it in countries with weak banking regulation. 
The structure of financial activity also influences its effect on growth. The above results indicate that a negative influence of intermediated credit and a positive one of stock markets lie behind the overall negative finance-growth link observed at the margin when looking at overall financial sector value added. The data show that households' borrowing has a negative marginal link with growth that is twice as large as firms' (Figure 5). Differentiated by type of lender, the negative link of bank credit with growth is about twice as strong as that of non-bank credit. This finding is in line with other recent empirical evidence that financial systems giving balanced roles to markets and banks are more conducive to economic growth than bank-dominated ones (Gambacorta et al., 2014; ESRB-ASC, 2014; Langfield and Pagano, 2015).

The destination of financial services also matters for growth. OECD-WTO data on trade in value added allow separating financial sector value added into domestic consumption and net exports. An empirical investigation indicates that financial sector value added has a more negative association with GDP growth when consumed domestically than when exported (Cournède and Denk, 2015). Similarly, the negative link between financial sector value added and growth is stronger when the sample excludes international financial centres (Figure 5). On the other hand, the import of financial services such as in the form of foreign-currency loans has been found to represent a source of instability (Ahrend and Goujard, 2011).

\section{Finance and income distribution}

This section investigates the influence of finance on the income distribution in OECD countries. It focuses on OECD countries and at times only on a European subset for reasons of data availability. The section first reports what the existing literature and new empirical analysis indicate about possible channels linking finance and income inequality. It then analyses what the data say about the sign of the net effect of these channels and discusses the direction of causality. Finally, the section presents simulations of what financial expansion implies for disposable income growth for different income groups.

\subsection{Possible transmission channels from finance to income inequality}

\section{Channels promoting income equalisation}

Financial deepening can benefit the poor disproportionately if it relaxes credit constraints that affect them more than the better-off (Beck, 2012). It allows the poor to realise potential high-return investments, including in their own education, that they cannot fund under shallower financial markets because they lack collateral and credit histories. Beck et al. (2007), Clarke et al. (2006) and Delis et al. (2014) identify supporting evidence for such an effect when analysing data covering a large number of developing countries. Bahmani-Oskooee and Zhang (2015) find that the improvement is only temporary in most countries where finance shows an equalising effect on the income distribution.

This pro-poor channel of financial development does not show up in micro-level data for euro area households. There seems to be no systematic link between the depth of credit intermediation and the share of credit going to the fifth of households with the lowest income levels, or to the next fifth of the income distribution (Figure 6 and Denk and Cazenave-Lacroutz, 2015). However, the sample refers to a rather narrow group of countries for a single year: more definitive assessments would require further analysis over more countries and time, which the euro area dataset used for this study does not permit.

Financial deepening could also help the poor indirectly by encouraging work in the formal sector and thus formal employment. Pagano and Pica (2012) report evidence that financial development is positively associated with employment growth in developing countries. The strength of this channel can in principle be expected to be weaker in advanced countries that have considerably smaller informal sectors than developing ones. 
Figure 6. Low income households do not benefit from deeper financial intermediation

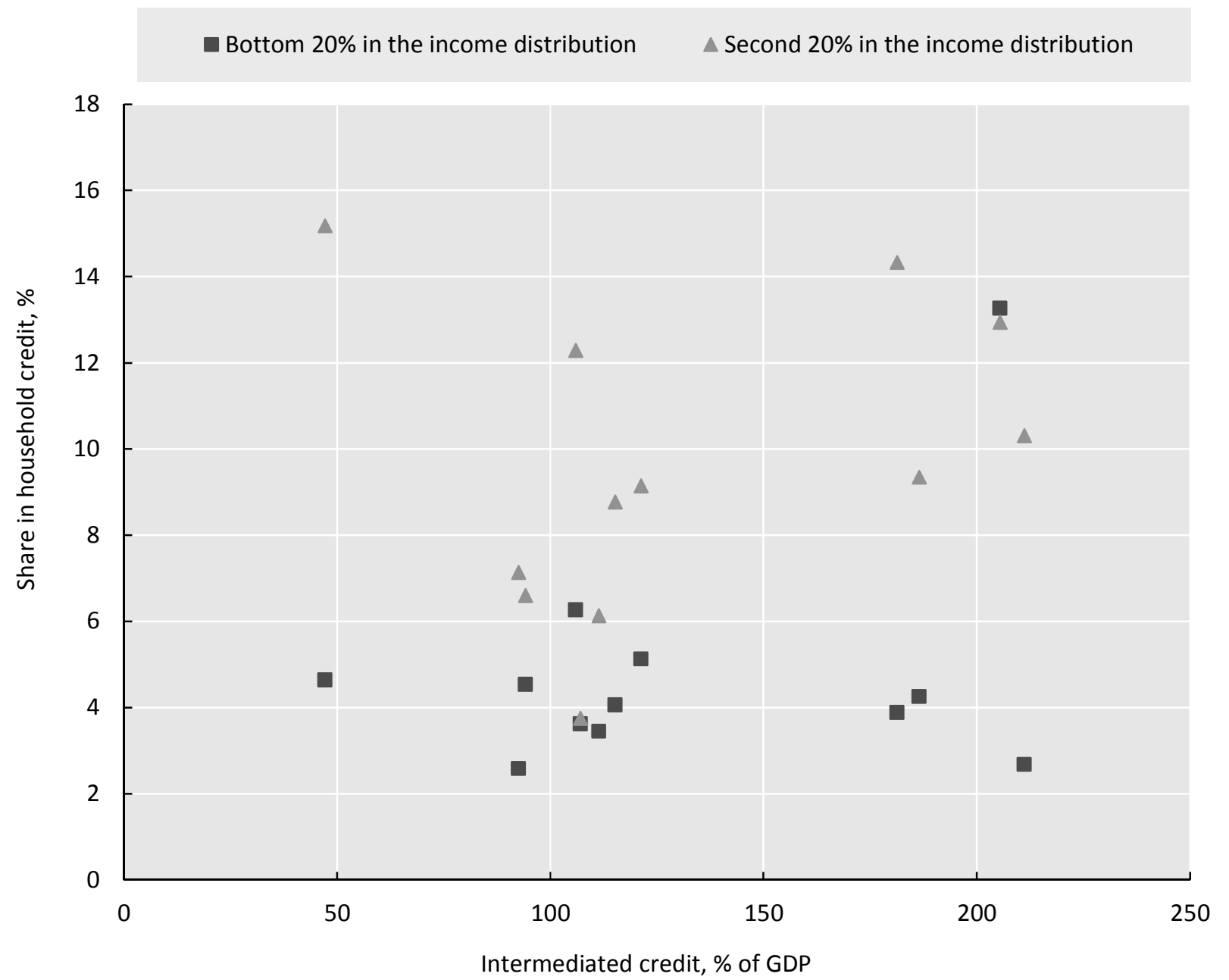

StatLink *ins http://dx.doi.org/10.1787/888933225392

Source: World Bank Global Financial Development database; ECB Household Finance and Consumption Survey; OECD Secretariat calculations described in Denk, O. and A. Cazenave-Lacroutz (2015), "Household Finance and Income Inequality in the Euro Area", OECD Economics Department Working Papers, No. 1226, OECD Publishing, Paris.

\section{Channels promoting income dispersion}

Conversely, greater financial depth can widen income gaps if it enables the better-off to obtain more or cheaper funding for the profitable projects that they can identify, compared with lower income people who would lack access to credit. This effect could arise in particular because the better-off typically have more collateral and better credit histories (Greenwood and Jovanovic, 1990). Micro-level data covering euro area countries show that low and middle income households face greater difficulty in obtaining credit than better-off households (Figure 7). As can be expected in consequence of these greater credit constraints, low income households have lower levels of borrowing, relative to disposable income, than their better-off counterparts (Denk and Cazenave-Lacroutz, 2015). However, low and middle income households on average do not pay higher interest rates than higher income households when they get credit (Denk and Cazenave-Lacroutz, 2015). 


\section{Figure 7. Low and middle income households find access to credit more difficult than high income ones}

Percentage of households expressing difficulty in obtaining credit among all credit-seeking households

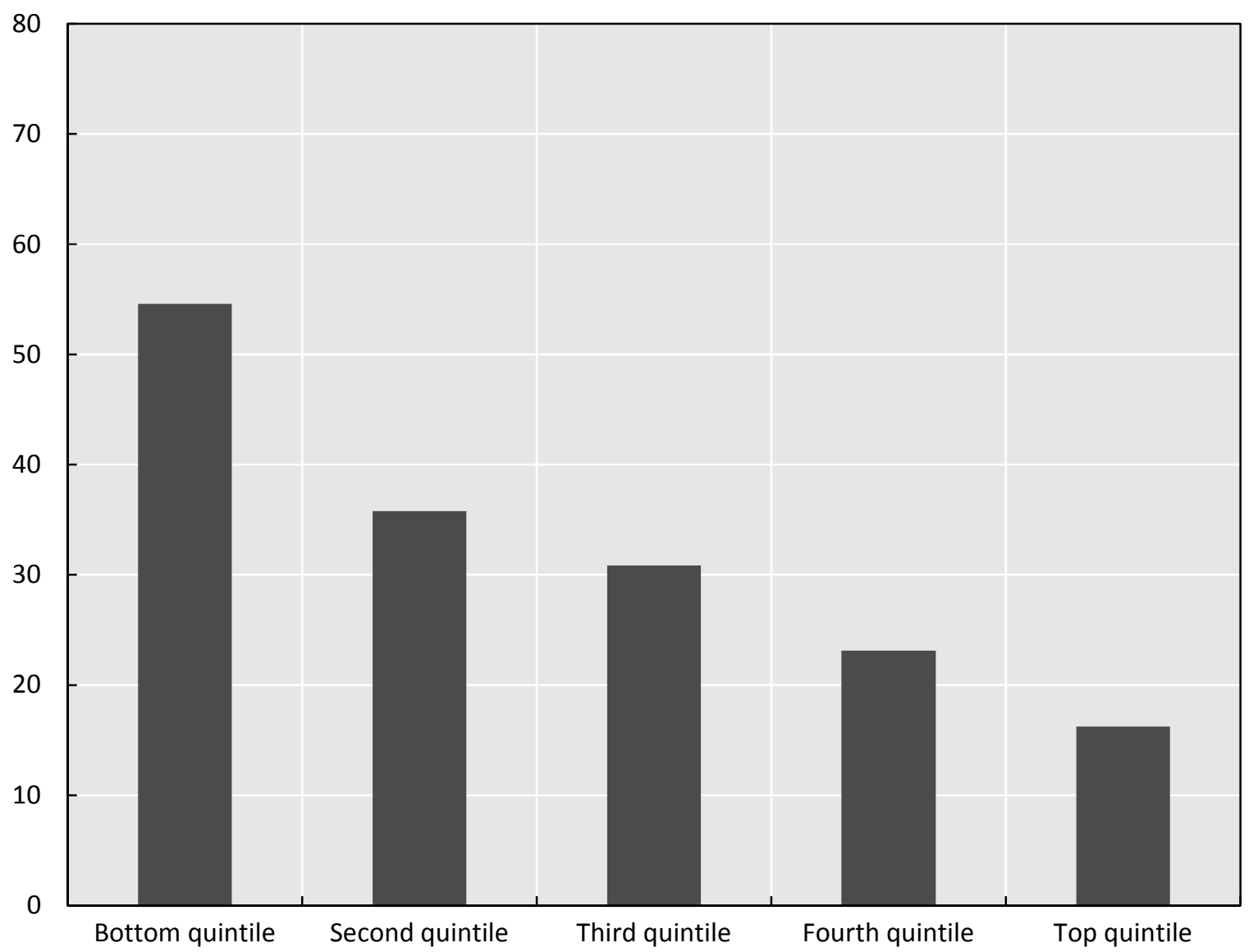

StatLink 凋S http://dx.doi.org/10.1787/888933225404

Source: ECB Household Finance and Consumption Survey; OECD Secretariat calculations described in Denk, O. and A. CazenaveLacroutz (2015), "Household Finance and Income Inequality in the Euro Area", OECD Economics Department Working Papers, No. 1226, OECD Publishing, Paris.

Borrowing is much more concentrated among low income households, so that those who do borrow tend to be much more leveraged than in other income groups (Denk and Cazenave-Lacroutz, 2015). This high leverage could create vulnerabilities or reflect predatory lending, although it could also manifest that the financial sector efficiently identifies low and middle income households with the best credit prospects.

Discrimination in the provision of credit against social groups who tend to have lower income could also exacerbate income dispersion. However, Denk and Cazenave-Lacroutz (2015) show that, in euro area countries, and accounting for observable characteristics, immigrants are more likely to hold credit than natives and women as likely to do so as men. The regressions control for age to account for the concern that the relation of credit with the life cycle may blur its relation with income levels.

The financial sector can also contribute directly to income inequality through the remuneration of its employees. Micro-level data for EU countries show that financial sector employees are concentrated in the upper end of the income distribution and especially in its top (Figure 8). This finding is in line with results by Fournier and Koske (2012) for OECD countries, Godechot (2012) for France, Bell and Van Reenen (2014) for the United Kingdom, as well as Bakija et al. (2012) and Philippon and Reshef (2012) for the 
United States. The micro-level EU data also show that pay is much more unequal in the financial sector than the rest of the economy, in line with Thewissen et al.'s (2013) finding for the United States and a group of European countries.

Figure 8. Financial sector employees are concentrated in the upper end of the income distribution

Percentage share of financial-sector employees in each percentile of the income distribution in European countries

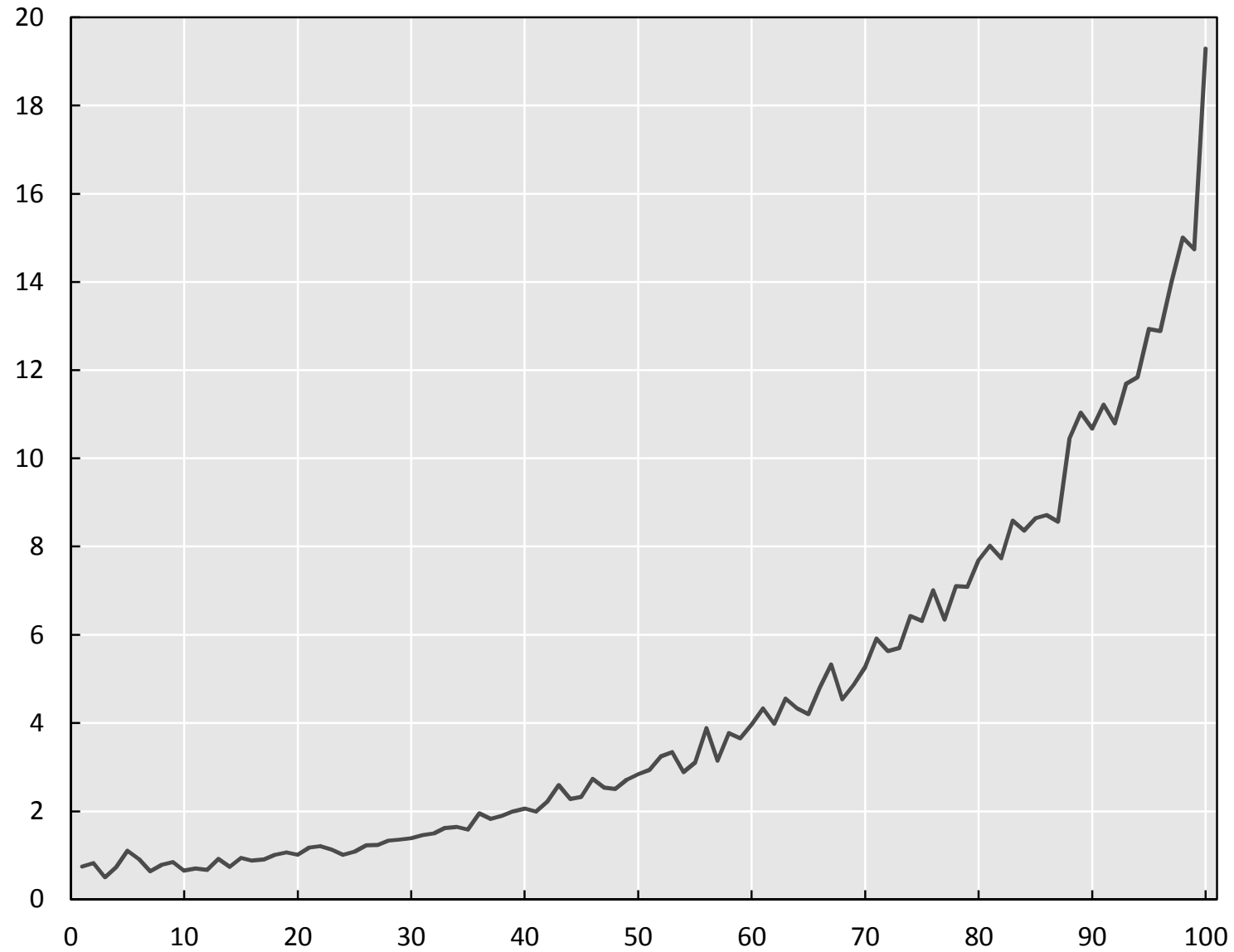

StatLink त्राजा http://dx.doi.org/10.1787/888933225414

Note: The figure depicts the simple average across EU countries for which data are available and Norway. It is calculated using Eurostat's micro-level Structure of Earnings Survey database for 2010. Data for Germany relate to 2006 . The sample size varies considerably across countries, and the coverage of sectors is not exactly the same in all countries.

Source: Denk, O. (2015), "Financial Sector Pay and Labour Income Inequality: Evidence from Europe", OECD Economics Department Working Papers, No. 1225, OECD Publishing, Paris.

High, dispersed financial sector pay contributes to overall income inequality in EU countries by an amount that is small but noticeable (Denk, 2015). This contribution is equal to 0.8 points of the Gini index, the most used measure of income inequality. To benchmark the relative magnitude of this contribution: the typical difference in Gini indices across OECD countries, calculated by the so-called "standard deviation", is equal to 5 points. ${ }^{4}$ Another comparison is that the Gini coefficient in OECD countries increased by 0.8 points between 1995 and 2010 . These numbers are reported only to provide a sense of scale: they do not imply that financial expansion explains the entire rise in income inequality over the 1995-2010 period.

4. This observation relates to the Gini index for income before taxes and transfers, which averaged 47 points across OECD countries in 2010. 
Two potential channels can explain the high level and dispersion of financial sector pay: the profile of financial sector employees in terms of education, age, experience, etc., and wage premia that raise wages above the compensation levels usually associated with their profiles. A detailed econometric investigation of micro-level EU data has looked at the degree to which education, age, years of work experience and a very extensive list of other relevant characteristics explain wages, which on average are $65 \%$ higher in finance than elsewhere (Denk, 2015). This investigation suggests that financial sector employees earn on average $28 \%$ more than their education, experience and other relevant characteristics can explain. Observable characteristics thus explain a little more than half of the pay difference between finance and other sectors. The micro-level data used to estimate wage premia refer to 2010 and therefore do not capture changes that may have occurred since then.

Furthermore, the financial sector wage premium increases along the wage distribution to reach $40 \%$ for the top $10 \%$ in the overall income distribution (Figure 9). Simulations indicate that the financial sector wage premium contributes 0.7 Gini points to economy-wide income inequality. A financial sector with no wage premium would therefore have almost no direct effect on income inequality, since only 0.1 Gini points would remain.

Several factors can explain these wage premia:

- The wage premia can reflect specific profit-generating skills in finance that are not captured by the individual characteristics that employers report in the data used for the estimation. For instance, finance could require particular curricula, while only broad information about educational attainment is available in the data.

- Higher financial sector compensation could in part remunerate longer working time than in other sectors in a way that the estimation does not fully take into account. The wage premia in principle control for effective working time because they adjust for paid overtime, but in practice overtime is unlikely well reported in the data and may not be explicitly paid, especially for professionallevel staff.

- Particular constraints on recruitment into finance, compared with other sectors, can contribute to wage premia. Empirical evidence for OECD countries over the 1980-2005 period is consistent with this view, as it shows a systematic association between higher wage premia and lower employment in finance (Denk, 2015). Obstacles complicating recruitment into finance could be related to the high levels of worker-specific human capital acquired on the job (Godechot, 2006; Meunier, 2007).

- Lack of competition for financial services could be another source of the wage premia. In particular, subsidies associated with public support such as too-big-to-fail guarantees can accrue to employees with bargaining power through higher wages, consumers through cheaper or more abundant borrowing, as well as other stakeholders involved in banks' business (Denk et al., 2015). Econometric investigations show a positive association between higher wage premia and deeper credit intermediation, a finding consistent with the possible presence of rent sharing (Cournède and Denk, 2015; Denk, 2015). 
Figure 9. Finance pays more than other sectors for workers with similar profiles especially at the top Estimated financial sector wage premium across the income distribution in European countries, \%, 2010

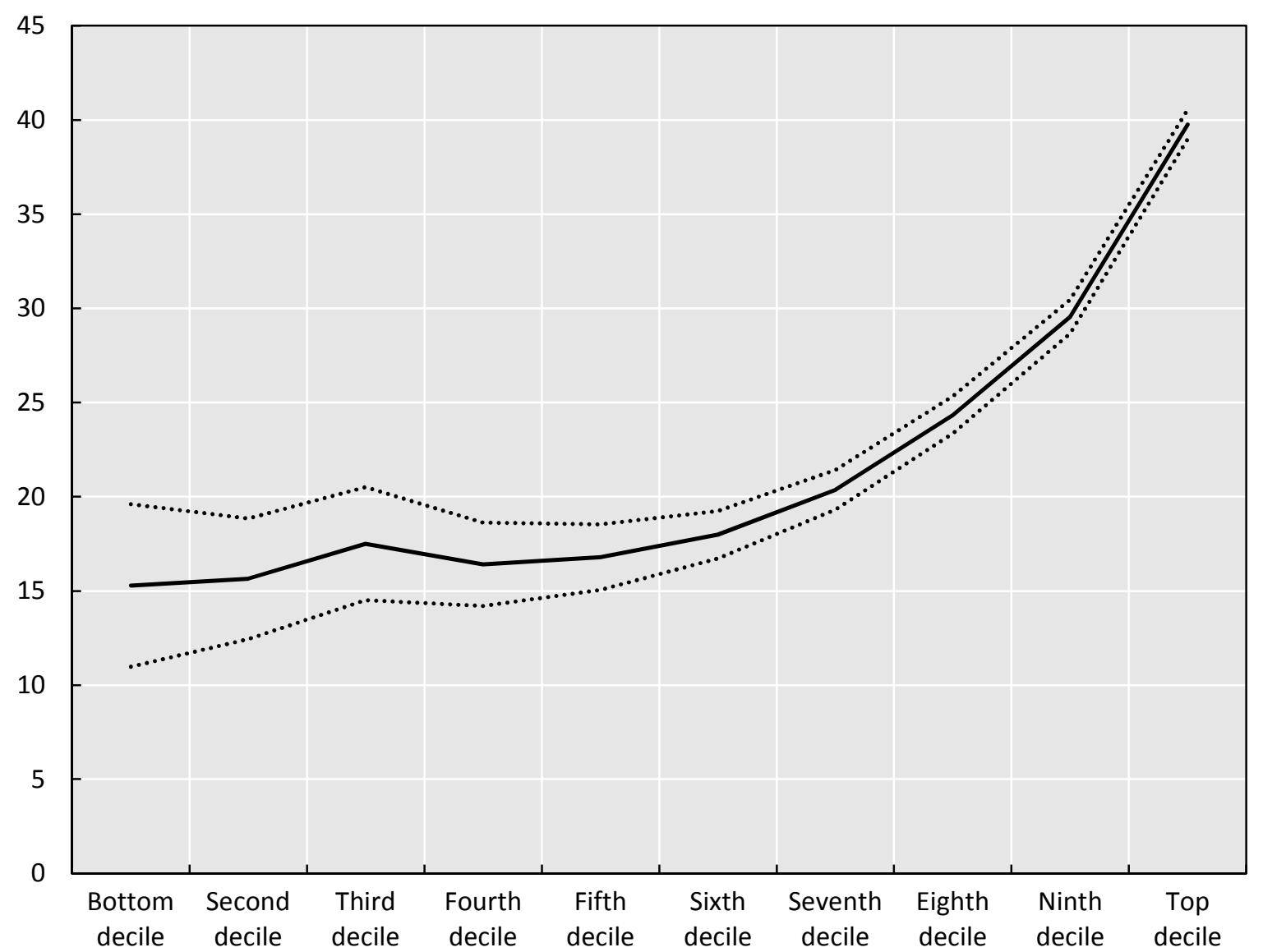

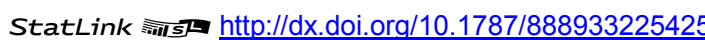
Note: The financial sector wage premium is the percentage by which gross annual earnings of weighted full-time full-year equivalent employees in finance exceed what other sectors pay. It is obtained from micro-econometric regressions controlling for age, gender, highest level of education, years of experience in the firm and their square, employees in the firm, geographical location of the firm, type of financial control, level of wage bargaining, type of employment contract, number of overtime hours paid and occupation. The estimates are computed using Eurostat's micro-level Structure of Earnings Survey database for 2010. Data for Germany relate to 2006. The chart depicts the simple average of EU countries for which data are available and Norway. The dotted lines represent the $90 \%$ confidence band.

Source: Denk, O. (2015), "Financial Sector Pay and Labour Income Inequality: Evidence from Europe", OECD Economics Department Working Papers, No. 1225, OECD Publishing, Paris.

Greater stock market capitalisation can also contribute to higher income inequality. The likelihood that households hold listed stock, directly or through funds, rises markedly with their income, and stock market wealth is even more concentrated among high earners (Denk and Cazenave-Lacroutz, 2015; Saiki and Frost, 2014). Therefore, larger stock markets, which generate more dividends and capital gains, can be expected to widen income inequality.

\subsection{New aggregate evidence on finance and income inequality in $\mathrm{OECD}$ countries}

The channels listed above point to both converging and diverging influences of finance on income distribution, which leaves the question of their net effect open. Econometric analysis for OECD countries over the past thirty years shows that more credit intermediation and more stock market financing are both associated with higher levels of income inequality (Figure 10). The results may underestimate the size of the link between stock markets and inequality because the underlying income statistics do not include 
capital gains (UNECE, 2011). The same analysis detects no statistically significant link between income inequality and financial activity measured by value added. This analysis employs the same methodology as for studying the finance-growth link summarised in Box 2 but substitutes the Gini coefficient for household disposable income inequality for the growth rate of GDP per capita and uses different control variables (see Section 2 of Denk and Cournède, 2015).

Figure 10. More credit intermediation and stock market financing are linked with greater income inequality Change in Gini coefficients for disposable income, Gini points

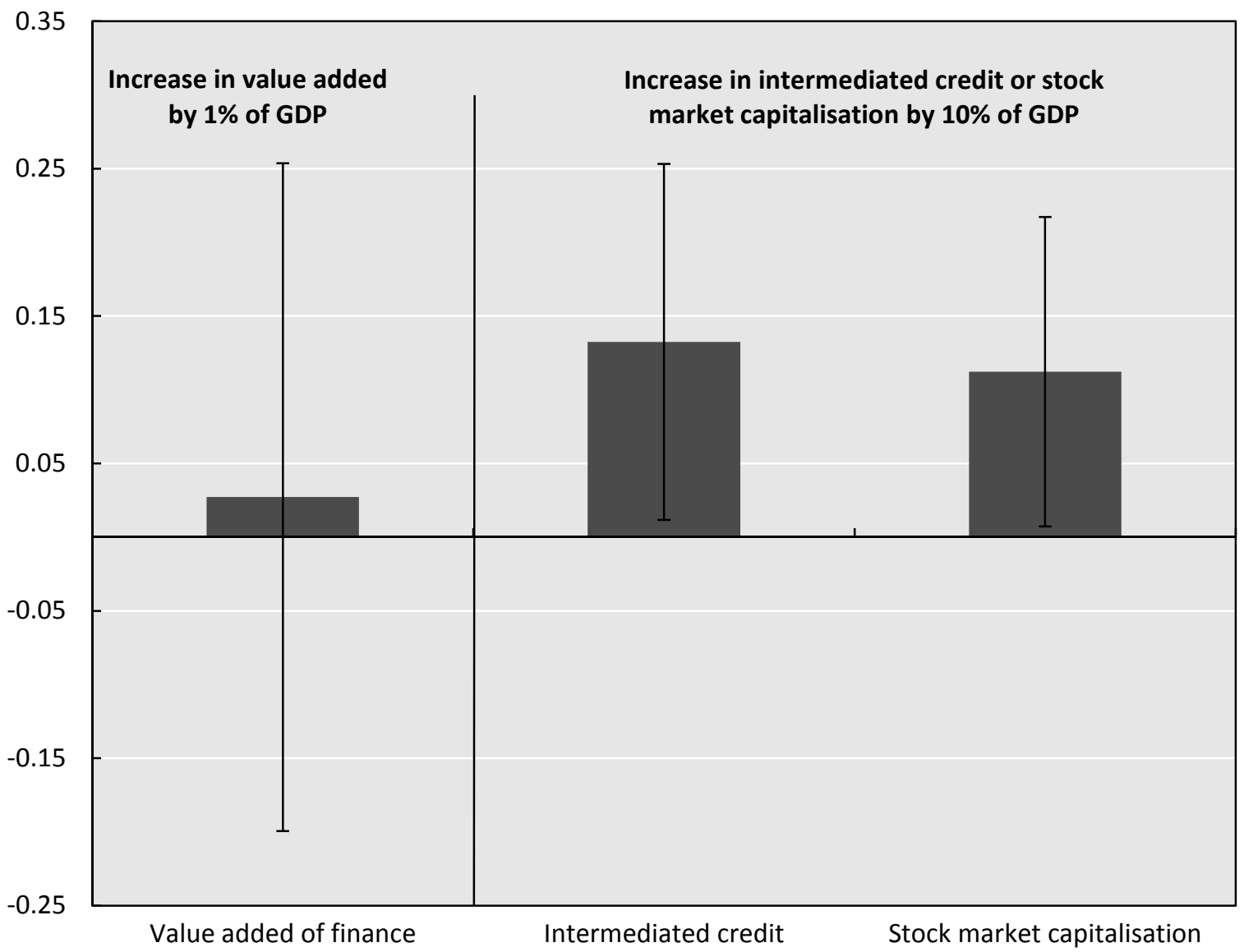

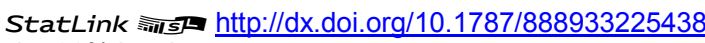
Note: The chart shows point estimates surrounded by confidence intervals at the $90 \%$ level.

Source: Denk, O. and B. Cournède (2015), "Finance and Income Inequality in OECD Countries", OECD Economics Department Working Papers, No. 1224, OECD Publishing, Paris.

\subsection{Robustness and causality of the estimated finance-inequality link}

The links of more credit intermediation or stock market financing with greater income inequality are established after taking into account a wide range of factors. Features of the data also provide indications of some causality running from more credit and larger stock markets to greater inequality.

\section{The links control for many potential drivers of the relationship}

Standard drivers of inequality

The specification controls for standard drivers of income inequality identified in the economic literature and previous OECD studies. They include unemployment, education and trade openness. 
Permanent country specificities

The estimation controls for time-invariant differences across countries. These controls eliminate effects of persistent country-level characteristics such as legal systems or other fundamental institutional features.

Trends and the role of technological change

The links are robust to controlling for country-specific time trends or year fixed effects or both. These checks highlight that the identified links reflect a relationship going beyond the mere observation that finance and income inequality both followed upward trends over the past forty years. Importantly, the results from these checks show that the estimated negative effect is not simply capturing the earnings dispersion generated by technological change.

\section{The results are robust to sensitivity checks}

\section{Financial crises}

The results remain broadly unchanged if abstracting from all banking crises identified by Laeven and Valencia (2012). Removing all observations since 2007 (as a rough way of controlling for the global financial crisis) yields coefficients that are smaller and statistically insignificant, probably because the size of the dataset is considerably reduced.

\section{Capital share}

More intermediated credit and larger stock markets, relative to GDP, may be correlated with a greater share of income going to capital. Financial expansion could then seem to reinforce income inequality merely because of its statistical association with rising wealth, which is much more unequally distributed than income (Piketty, 2014). Regressions have been run adding the labour share as a control to check this hypothesis. Extending the analysis in this way reduces the sample size, and this reduction in sample size has the effect that the coefficients stop being statistically significant. Adding the labour share to the specification does not materially change the results beyond the effect due to the sample-size reduction.

\section{The economic literature and the data provide indications about causality}

\section{Economic literature}

These links between finance and inequality raise questions of causality. ${ }^{5}$ More credit could also result from, rather than only cause, greater income inequality. This reverse causality could occur if low earning households borrowed more to avoid too large consumption disparities when income inequality is high. This is conjectured by Rajan (2010), Kumhof et al. (2015) and van Treeck (2014) consistent with studies using US time series (Pollin, 1988; Christen and Morgan, 2005; Boushey and Weller, 2008). On the other hand, Atkinson and Morelli (2011) and Bordo and Meissner (2012) found no support for this hypothesis after analysing the international experience using case studies and macro-level data. However, Gu and Huang (2014) find a causal link from higher inequality to credit booms and financial crises in a cross-country dataset. Overall, the economic literature is inconclusive on this subject.

5. The instrumental variables approach employed to examine causality in the finance-growth nexus could not be replicated for inequality because the sample is too small. 


\section{Micro-level evidence}

Two features of recent micro-level data go against the hypothesis of causality running entirely from greater inequality to more credit and suggest instead that at least some degree of causality runs from more credit to greater inequality:

1. People with incomes well below the median show no signs of borrowing more, as a share of total credit or as a ratio to their income, in more unequal countries across the euro area (Section 3 of Denk and Cournède, 2015). Coibion et al. (2014) come to the same conclusion across US states.

2. The link between more credit and higher income inequality could be expected to be tighter for households than for businesses if it resulted from poor people borrowing more in more unequal countries. However, cross-country data for OECD countries exhibit the opposite relationship: business credit is more negatively associated with income equality than household credit (Section 3 of Denk and Cournède, 2015).

\section{Direct effect of financial sector pay}

The size of the direct effect of financial sector compensation provides further indication that causality flows at least partly from a larger financial sector to greater income inequality. Back-of-the-envelope calculations, based on the direct estimates in Section 4.1, suggest that the remuneration of financial sector employees explains about one half of the aggregate link between the size of credit intermediation and inequality shown in Figure 10. Reverse causality has not been investigated for the link with stock markets, because greater income inequality seems unlikely to boost stock market capitalisation.

\subsection{Implications of financial expansion across the income distribution}

Simulations have been undertaken to gauge what the finance-inequality links mean for the income growth of various income groups. These simulations use three inputs:

- First, estimates of the impact of financial outcomes on household income growth (Section 4.2 of Denk and Cournède, 2015);

- Second, the estimates discussed above of the effect of finance on income inequality measured by the Gini coefficient;

- Third, estimated mappings from changes in Gini coefficients to decile-by-decile income shares (Section 4.3 of Denk and Cournède, 2015).

This method uses a considerably richer dataset, and therefore is likely to be much more reliable overall, than estimating directly the link between changes in financial indicators and the income growth of different groups (see Denk and Cournède, 2015, for a more extended discussion of the validity of this approach).

Econometric analysis finds that intermediated credit and stock market capitalisation have very similar links with household disposable income growth as with GDP growth. The estimated associations with average household disposable income growth are:

- $\quad$ negative for more intermediated credit, and

- positive for greater stock market capitalisation.

The simulations suggest that an increase in credit intermediation is typically accompanied by slower income growth for $90 \%$ of the population but higher income growth for the top 10\% (Figure 11, Panel A). Similar simulations suggest that an expansion in stock markets in general comes with higher income growth for most of the population but not for the bottom 30\% (Figure 11, Panel B). The simulations may underestimate the effects of stock market expansion since the underlying data do not include capital gains, as mentioned above. 
Figure 11. Simulated effects of credit and stock market expansion vary across the income distribution A. Link between household income growth for different deciles and a $10 \%$ of GDP expansion of intermediated credit

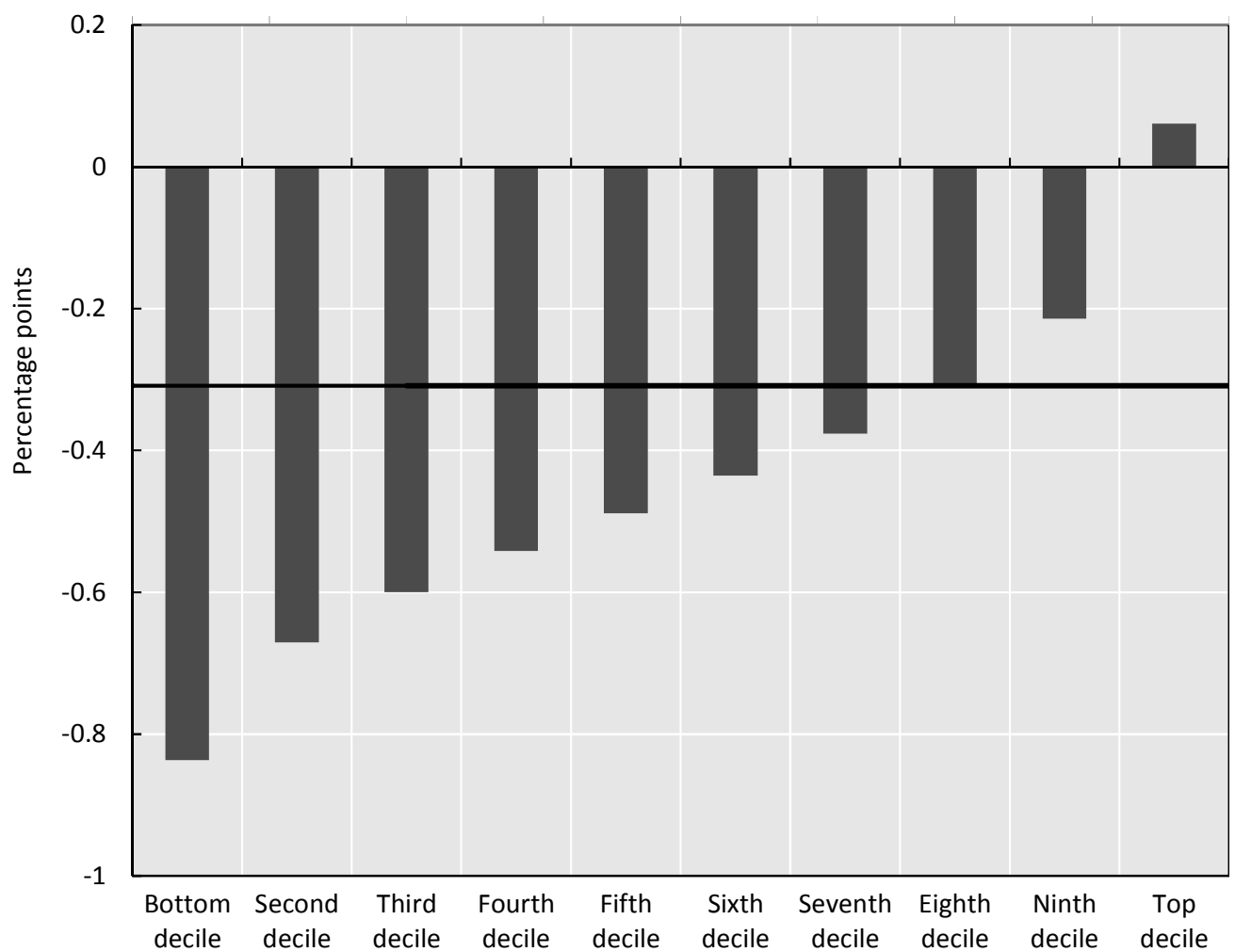

B. Link between household income growth for different deciles and a $10 \%$ of GDP rise in stock market capitalisation

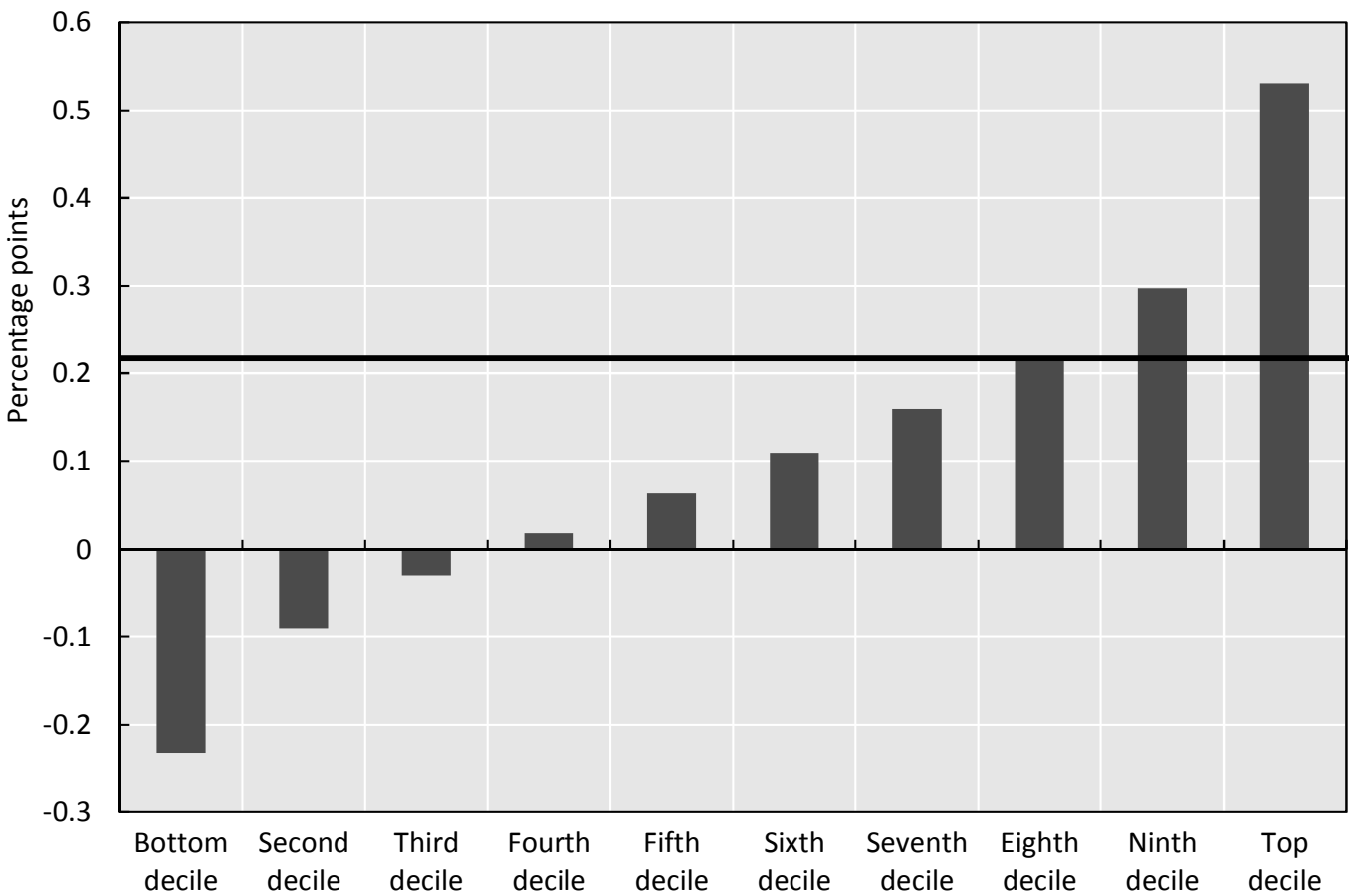

StatLink : inlst http://dx.doi.org/10.1787/888933225443 Note: Household income growth is household disposable income growth per capita. Stock market capitalisation is the value of all shares listed in a stock market. The horizontal line indicates the change in household income growth for the economy as a whole.

Source: Denk, O. and B. Cournède (2015), "Finance and Income Inequality in OECD Countries", OECD Economics Department Working Papers, No. 1224, OECD Publishing, Paris. 


\section{Policy considerations}

The empirical analyses have implications for financial reform to support inclusive growth. In particular, the data indicate that credit intermediaries may have developed in most OECD countries to a point where further expansion is at the margin associated with slower long-term economic growth and greater economic inequality. This observation relates to fundamental trends and not to the current situation where flows of new borrowing and lending remain low in parts of the OECD area. The data also point to some degree of causality running from more credit intermediation to slower growth and higher inequality.

The results therefore suggest that financial reform addressing market and government failures in the financial sector can bring substantial benefits for income growth and equality, even if it involves some downward adjustment to the long-term level of credit intermediation. In other words, there is not necessarily a long-term trade-off between financial reform affecting credit provision, growth and income equality.

One important caveat is that the empirical work has focused on permanent effects. Financial reform that would curb credit growth can however weigh on activity in the short to medium term.

The rest of the section reviews financial reforms in the areas of regulation, labour-market policy and taxation, which would lead to a better functioning financial system. The empirical analysis finds a link at the margin from financial deregulation, measured by an aggregate indicator, to credit expansion and slower growth. However, it did not investigate the direct effects of each financial policy item on growth and inequality outcomes for lack of data that would cover the policy stance of enough countries item by item for long enough. Instead, financial policy items are discussed based on their effects on financial outcomes and on the above empirical evidence about how these financial outcomes influence growth and inequality. The text does not cover other areas of financial reform, such as credit-rating agencies, risk weighting, overthe-counter derivatives, accounting standards and unique global legal-entity identifiers for parties to financial transactions, which are not directly related to the empirical findings of the project.

\subsection{Financial regulation}

The links from too much credit to slower growth and greater income inequality underline the longterm benefits of reforms that fend off credit overexpansion and better align incentives with long-run performance. Banking and prudential reforms to avoid accumulating too much debt could, however, restrict credit provision weighing on activity in the short term.

\section{Banking regulation}

The particularly strong negative association between increases in bank lending and economic growth underscores the benefits of reducing explicit and implicit subsidies to the banking sector. The empirical evidence uncovered signs of rent sharing, including the presence of substantial financial sector wage premia and their correlation with high levels of credit intermediation (Cournède and Denk, 2015). De facto subsidies for bank debt appear to generate distortions that slow growth (Denk et al., 2015).

Strong requirements on lenders to maintain large capital buffers reduce the extent to which banks can fund lending through liabilities that benefit from public support, such as insured deposits or other forms of debt at too-big-to-fail (TBTF) lenders. The Basel III framework goes in this direction especially by requiring that banks finance at least 3\% of their total assets with equity. Blundell-Wignall and Roulet (2013) provide evidence that banks funding more of their assets with equity are at much lower risk default. In addition to reducing distortive bank subsidies, stronger capital requirements reduce the economic cost and severity of crises, also boosting long-term growth (BCBS, 2010; Miles et al., 2012). 
One way of phasing out de facto public support to systemically important financial institutions would be to split currently TBTF banks into entities sufficiently small that they could go bankrupt without creating systemic risk. In a different sector, the 1982 break-up of AT\&T by US anti-trust authorities into 17 independent companies is one example of splitting a very large, systemic company operating complex networks. Costs could arise through the loss of economies of scale in the banking sector, but much of the empirical literature finds that financial activities involve no significant economies of scope or scale beyond a relatively small size (see Amel et al., 2004, for a survey). Recent research finds that apparent economies of scale at very large banks vanish when adjusting for too-big-to-fail subsidies (Davies and Tracey, 2014). A drawback of break-ups could be that a large number of small banks could conceivably accumulate as much systemic risk as a small number of TBTF banks.

Public authorities can follow alternative approaches to splitting TBTF banks. They can in particular: impose capital surcharges on TBTF banks, require TBTF banks to present credible resolution plans (socalled "living wills"), encourage the separation of TBTF banks' more risky activities from their systemic utility functions (Blundell-Wignall and Atkinson, 2012; Blundell-Wignall and Roulet, 2013) and ensure a wider participation of the private sector in the sharing of losses of insolvent banks. Many OECD countries are currently pursuing reforms along these lines at the national and international level in particular under the auspices of the European Union and the Basel Committee for Banking Supervision (BCBS).

In practice, the capital surcharges implemented by Basel III (BCBS, 2011) seem unlikely to induce TBTF banks to fully internalise the value of de facto TBTF subsidies. As of end-2014, the Financial Stability Board (FSB) identified no bank as requiring a capital surcharge of $3 \frac{1}{2}$ per cent of risk-weighted assets while only two were classified in the bucket where a $2 \frac{1}{2}$ per cent surcharge applies. This surcharge can be compared to the level that would be needed to offset the reduction in funding cost that results from explicit and implicit guarantees. Schich et al. (2014) estimate that public backing reduced the funding costs of a sample of large European banks by 1.3 percentage points in 2013. A rough calculation using the funding-cost difference between equity and other liabilities suggests that a capital surcharge of about $13 \%$ of unweighted assets would be needed to offset the funding advantage generated by public backing (see Appendix 2 of Cournède and Denk, 2015).

Tight bank regulation could have the effect of pushing risk to other compartments of financial markets, such as the so-called "shadow banking" sector. A migration of risk from institutions that benefit from de facto public support to parts of the market where investors are more likely to absorb losses themselves does not represent a problem but is rather a welcome effect of regulating banks more tightly. Such risk migration can however become an issue, and a source of instability, if parts of the financial system accumulate risk that can generate overall instability and therefore become systemic. This concern requires that financial supervision authorities maintain their efforts to monitor risks on a system-wide basis rather than for particular players in the financial system.

\section{Macro-prudential regulation}

The link of more intermediated credit with slower growth and higher income inequality also highlights the benefits of using macro-prudential measures to avoid credit overexpansion. Caps on debtservice-to-income have been identified as particularly effective in this regard (Kuttner and Shim, 2013). Evidence in Cournède and Denk (2015) suggests that, when credit increases, too much capital is allocated to house building through housing loans. This finding underlines an additional advantage of macroprudential measures, which can focus on specific sectors such as housing. Reforms to reduce public support for institutions that channel savings towards housing loans would also help reduce the build-up of risk and possible misallocation of capital associated with too much housing finance. Macro-prudential measures and the winding down of support for mortgages raise, however, the political-economy difficulty that, at the time of their adoption, such reforms make it more difficult for buyers with limited resources to buy residential property. 


\section{Compensation reform}

The substantial financial sector wage premia earned by highly-skilled workers above what they would typically earn in the rest of the economy contribute to overall income inequality (Denk, 2015). Tentative evidence from the OECD Survey of Adult Skills (PIAAC) also indicates that financial sector workers are more likely to be overskilled than those working elsewhere, even if the magnitude of the difference to other sectors is small. Furthermore, high wages can draw the most talented workers into the financial sector where they may not contribute as much to economic growth as compared to jobs in sectors with greater potential for productive innovation (Tobin, 1984; Cecchetti and Kharroubi, 2015). This potential negative effect on growth through misallocation of talent is similar to the one that has been documented in less developed countries where the prospect of rent-seeking attracts the highest-skilled individuals into the public sector rather than more productive private activities (Acemoglu and Verdier, 1998). US state-level experience provides evidence that labour productivity falls when finance absorbs skilled people (Kneer, 2013).

The presence of wage premia implies that reforms to improve compensation practices in the financial sector with regard to stability or perceptions of fairness are unlikely to hurt growth. For instance, restricting asymmetric pay, which rewards short-term successes without taking back the awards in cases of subsequent poor performance, should not prevent the financial sector from attracting sufficiently skilled workers, even if it implies lower compensation levels. Korinek and Kreamer (2014) propose a model suggesting that restricting asymmetric pay is also likely to lead to greater income equality.

As in other sectors, the case for tackling gender-based pay discrimination is strong in the financial sector. Men working in the financial sector earn a substantial wage premium over women with similar profiles who also work in the sector. In several countries, this male wage premium is greater in finance than the rest of the economy, hinting at the presence of particularly discriminatory practices (Denk, 2015).

\subsection{Tax policy}

\section{Tackling the debt bias in corporate taxation}

The empirical results reported above suggest that in most OECD countries more debt is typically associated with slower growth while more stock market financing generates a positive growth effect. Furthermore, recent OECD work (Ahrend and Goujard, 2012) found that corporate tax systems which favour debt over equity are associated with a higher share of debt in external financing, thereby increasing financial crisis risks. The economic literature and earlier OECD work identified that the debt bias in corporate taxation generates costly economic distortions (De Mooij, 2012; Devereux et al., 2013; OECD, 2007). These findings all underline the growth benefits of reducing the debt bias in corporate taxation. Effective average tax rates on equity finance generally exceed those on debt finance, primarily because interest expenses are cost-deductible (Figure 12). 
Figure 12. Tax systems favour debt over equity financing

Percentage point difference between the effective average tax rates on equity and debt finance, 2011

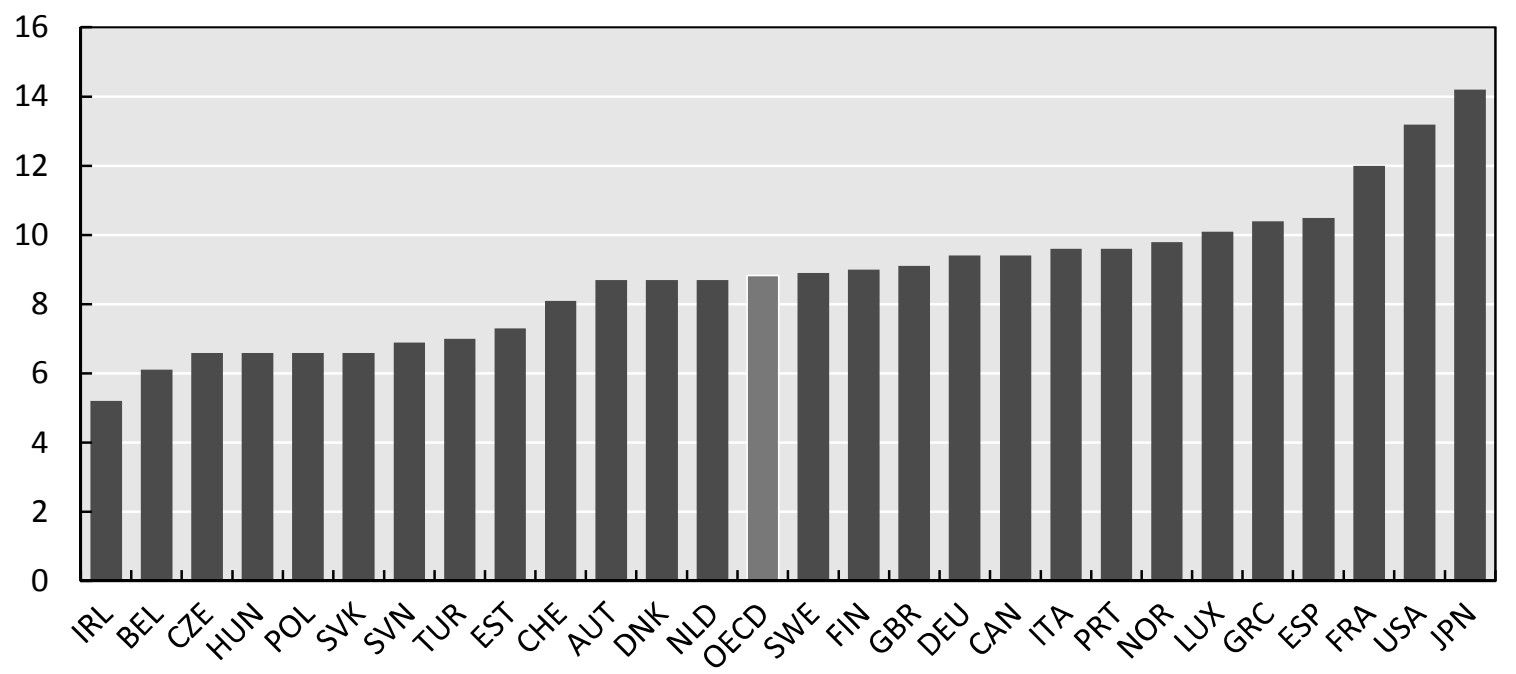

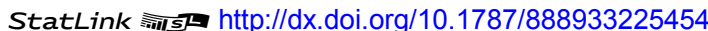
Note: OECD is the simple average of OECD countries for which data are available. The calculations account for taxes levied at the corporate level but not for those paid at the personal level. In many countries, the majority of investments are financed by foreign investors (to whom the domestic personal income tax does not apply) and by investors exempt from the personal income tax (especially pension funds and charitable foundations). The effective average tax rates on equity finance apply to new equity.

Source: OECD Secretariat calculations based on Centre for European Economic Research (2011), Effective Tax Levels Using the Devereux/Griffith Methodology, Project for the EU Commission, TAXUD/2008/CC/099, Mannheim.

\section{Phasing out the housing bias}

Tax provisions related to housing taxation can slow potential growth by distorting the allocation of capital in favour of housing. Results reported above underscore that, at the margin, increases in household debt, which predominantly finances house purchases, exhibit a comparatively strong negative association with GDP growth. Tax provisions that favour mortgages also tend to increase the fragility of the financial system by subsidising excessive borrowing of households (Caballero et al., 2014). In principle, mortgage interest relief, common in many OECD countries, ensures that home buyers are taxed equally irrespective of the extent to which they borrow, or not, to fund their purchase. In practice, interest expenses on housing loans are often deductible at a higher rate than the one at which investment income (for instance from life insurance or pension funds) is taxed, although the deductible amount is often limited. In addition, because interest relief is typically restricted to loans that are taken for a house purchase, it creates a bias towards housing, which is amplified by the widespread exemption of owner-occupied housing services from taxable income (Denk, 2012; Égert, 2013). This bias can encourage over-investment in housing compared with other forms of capital. Steps to lower the tax advantage of housing include the taxation of imputed rents and capital gains from owner-occupied housing, increasing property taxation on owner-occupied housing, rolling back mortgage interest relief for owner-occupied housing and reducing the taxation of other asset classes.

\section{Reducing the VAT bias against business lending}

Furthermore, the value-added tax (VAT) exemption of deposit and lending services applied in most OECD countries favours household over business credit. The empirical results summarised above report a stronger negative effect of household than business credit on growth, suggesting that bringing deposit and lending services under VAT should support growth. Under the exemption rules prevailing in most OECD countries, lenders do not recuperate VAT on the inputs they are purchasing. This treatment means that, 
indirectly through margins between lending and deposit rates, business borrowers bear the cost of the irrecoverable VAT incurred by lenders on the inputs they use to grant the business credit. This indirect payment would not occur under a standard VAT treatment of deposit-and-lending, which would carry the burden of VAT through to final consumers. On the other hand, households do not pay VAT on the value added created by lenders which is embedded in household credit. Therefore, household credit is undertaxed relative to a standard VAT treatment. Consequently, the VAT exemption of deposit and lending services creates a bias in favour of household relative to business lending. Different options can be considered to extend VAT to lending and deposit-taking (Box 3).

\section{Box 3. Possible ways of extending VAT to deposit-taking and lending services}

Different approaches can be followed to extend VAT to deposit and lending services. The IMF (2010) and the Mirrlees Review (2011) argued that the administrative difficulties did not seem insurmountable although no VAT system has been widely implemented for deposit and lending services. Following Poddar and English (1997), practical approaches have in common the idea of charging financial intermediaries VAT on cash inflows (e.g. cash deposits, loan repayments) and refunding VAT to financial intermediaries on cash outflows (e.g. cash withdrawals, loan disbursements). This framework is akin to treating cash inflows into financial intermediaries as sales and outflows as purchases with the nuance that VAT is recuperated by the intermediaries rather than their clients. This is needed in particular to avoid that Treasuries have to refund VAT to every individual with a bank account. Instead of imposing or recovering VAT on each cash flow, the calculation could be simplified by charging VAT on a bank's net cash inflow (for example over the course of a month or year).

An alternative is the Financial Activities Tax (FAT), a form of which was adopted by Iceland, which would tax the profits and wages of financial institutions. Although such a FAT has in common with a VAT extension that it taxes financial sector profits and wages, it raises some design issues including how to refund it for business customers and to adjust it at the border (Keen et al., 2010). Experimental pilots with volunteer banks in Europe during the 1990s found the VAT extension to be robust and practical (Poddar, 2007), while involving non-negligible compliance costs (Edgar, 2007).

\section{Recuperating too-big-to-fail subsidies through taxation}

Finally, tax policy can also serve as a second-best way of correcting implicit subsidies flowing to TBTF banks if financial reform cannot eliminate the TBTF guarantee entirely. A recent OECD study of 95 large European banks (Schich et al., 2014) reckons that government support reduces the cost of their long-term funding by 1.3 percentage points, which is worth EUR 60 billion per year ( $0.4 \%$ of EU GDP). Haldane (2012) estimated that the 29 banks identified as global systemically important financial institutions by the FSB benefited from implicit subsidies worth USD 500 billion per year, or $1.1 \%$ of OECD GDP in 2011. ${ }^{6}$ These estimates, though surrounded by large uncertainties, indicate that fully recuperating TBTF subsidies through taxation could bring in a large amount of revenues. Taxing TBTF subsidies could also bring tax revenues indirectly through the positive effect of correcting this distortion for economic growth. Pricing TBTF subsidies, however, implies acknowledging them as explicit rather than implicit, which could complicate efforts to withdraw them (Schich and Aydin, 2014). Reducing TBTF subsidies would also improve financial stability, as TBTF banks tend to take more risk than otherwise comparable banks (Afonso et al., 2014; Marques et al., 2013; Ignatowski and Korte, 2014; Mattana et al., 2014).

6. The sample in Haldane (2012) refers to the first list of global systemically important financial institutions established by the FSB at the end of 2011. Scaling by OECD GDP is imperfect as the sample includes one non-OECD bank. The methodology behind this estimate is presented and compared with alternatives in Noss and Sowerbutts (2012). Elliott (2014) references additional estimates with a US focus. 


\subsection{Financial reforms: win-win, income-enhancing and opposite effects on growth and equality}

The reforms suggested above are all meant to improve long-term GDP and average household income growth, but they can have different consequences for income inequality:

- The empirical results reported in the previous sections suggest that reforms keeping the size of finance in check are likely to favour less income inequality compared with a status quo that implies more credit or greater stock market capitalisation. These measures, listed at the top of Table 2, are "win-win" for growth and income equality. Reducing implicit and explicit housing subsidies in taxation and mortgage finance is included in this group as it is likely to reduce overall credit through its effect on mortgages, thereby improving growth and equality in the long term. Cuts to subsidies in housing taxation and mortgage finance not accompanied by targeted relief measures may have adverse distributional effects in the short term but not in the long term, when house prices fully reflect the value of such subsidies.

- Measures to improve the composition of finance do not appear to affect income inequality and can thus be expected to lift the growth of income across its distribution. Shifting funding from debt toward stock market financing has no clear effect on the income distribution given that both forms of finance have similarly sized impacts on inequality measured by the Gini coefficient (Figure 10). Similarly, measures resulting in shifts from bank- to market-based debt have no obvious effects on income inequality. Value-added and corporate tax reforms to reduce biases favouring debt in general and bank debt in particular belong to this category of "incomeenhancing" measures (Table 2).

- Some measures could boost growth and result in greater income inequality, prompting a trade-off between the two objectives. This appears to be the case for lowering barriers to stock market financing. Taken at face value, the simulation exercise summarised above suggests that larger stock markets can even slow the income growth of some of the less well-off. The adverse distributional effects of stock market expansion can be addressed, however, by facilitating stock market participation by the less well-off, for instance through nudging in pension schemes. However, evidence that the less well-off tend to get lower stock returns (Calvet et al., 2008; Guiso et al., 2003) calls for appropriate safeguards including through financial education.

Table 2. Win-win, income-enhancing and opposite effects on growth and equality of selected financial reforms

\begin{tabular}{|c|c|c|}
\hline & Growth & Equality \\
\hline \multicolumn{3}{|l|}{ Win-win } \\
\hline Require high bank capital buffers & + & + \\
\hline Enforce strong macro-prudential controls & + & + \\
\hline Split TBTF banks or reduce TBTF support through other means & + & + \\
\hline Recuperate TBTF subsidies through taxation & + & + \\
\hline Reduce implicit and explicit housing subsidies in taxation and mortgage finance & + & + \\
\hline \multicolumn{3}{|l|}{ Income-enhancing } \\
\hline Reduce the debt bias in corporate taxation & + & \\
\hline Reduce the bias against market-based finance in VAT & + & \\
\hline \multicolumn{3}{|l|}{ Trade-off } \\
\hline Reduce barriers to stock market financing & + & - \\
\hline
\end{tabular}


Appendix 1. Measuring financial sector value added: Broad principles and limitations

Financial services can be charged directly or remunerated indirectly through margins between bank lending and deposit rates. The national accounts measure activities directly charged in the same way as other services but apply modelling assumptions for services that are paid for indirectly. The present report uses statistics on financial sector value added which are compiled in the OECD Structural Analysis (STAN) database in accordance with SNA (1993) guidelines. To simplify, under this methodology, the value of bank lending services is calculated as the value of loans times the spread between the interest rate charged and a reference rate. Similarly, the value of deposit-taking services is equal to their amount times the spread between the reference rate and the rate at which they are remunerated. The same reference rate is used for each operation irrespective of its risk, as the management of maturity risk and credit default risk is considered part of the normal business of banks. This calculation method implies that a build-up of risk may translate into an increase in financial sector value added (Haldane et al., 2010).

The new SNA (2008) guidelines also recommend applying a single reference rate but open a possibility to exclude credit default risk, especially in the case of an "excessive" build-up of risks. This leeway in the valuation of indirectly measured financial services could lead to cross-country differences. Besides, Everett et al. (2013) have argued that the materialisation of risk should be subtracted from the measurement of financial services. Basu et al. (2011) and Haldane et al. (2010) estimate that adjusting for risk would reduce the measured size of the financial sector by about $20 \%$ in the United States and $40 \%$ in the United Kingdom. 


\section{References}

Abiad, A., E. Detragiache and T. Tressel (2010), "A New Database of Financial Reforms", IMF Staff Papers, Vol. 75, Issue 2.

Acemoglu, D. and T. Verdier (1998), "Property Rights, Corruption and the Allocation of Talent: A General Equilibrium Approach", Economic Journal, Vol. 108, Issue 450.

Admati, A. and M. Hellwig (2013), The Bankers' New Clothes: What's Wrong with Banking and What to Do about It, Princeton University Press, Princeton, New Jersey.

Afonso, G., J. Santos and J. Traina (2014), “Do Too-Big-To-Fail Banks Take On More Risk?," Federal Reserve Bank of New York Economic Policy Review, Vol. 20, Issue 2.

Ahrend, R. and A. Goujard (2011), "International Capital Mobility and Financial Fragility - Part 1: Drivers of Systemic Banking Crises", OECD Economics Department Working Papers, No. 902, OECD Publishing, Paris.

Ahrend, R. and A. Goujard (2012), "International Capital Mobility and Financial Fragility - Part 3: How Do Structural Policies Affect Financial Crisis Risk? Evidence from Past Crises across OECD and Emerging Economies", OECD Economics Department Working Papers, No.966, OECD Publishing, Paris.

Amel, D., C. Barnes, F. Panetta and C. Salleo (2004), "Consolidation and Efficiency in the Financial Sector: A Review of the International Evidence", Journal of Banking \& Finance, Vol. 28, Issue 10.

Arcand, J.-L., E. Berkes and U. Panizza (2012), “Too Much Finance?”, IMF Working Papers, No. 12/161.

Arnold, J., A. Bassanini and S. Scarpetta (2011), "Solow or Lucas? Testing Speed of Convergence on a Panel of OECD Countries", Research in Economics, Vol. 65, Issue 2.

Atkinson, A. B. and S. Morelli (2011), "Economic Crises and Inequality", Human Development Research Paper, No. 2011/06, UNDP.

Bahmani-Oskooee, M. and R. Zhang (2015), "On the Impact of Financial Development on Income Distribution: Time Series Evidence", Applied Economics, Vol. 47, Issue 12.

Bakija, J., A. Cole and B. T. Heim (2012), "Jobs and Income Growth of Top Earners and the Causes of Changing Income Inequality: Evidence from US Tax Return Data", Williams College, US Department of Treasury and Indiana University.

Bassanini, A., S. Scarpetta and P. Hemmings (2001), "Economic Growth: The Role of Policies and Institutions: Panel Data Evidence from OECD Countries", OECD Economics Department Working Papers, No. 283, OECD Publishing, Paris. 
Basu, S., R. Inklaar and J. C. Wang (2011), "The Value of Risk: Measuring the Service Output of US Commercial Banks", Economic Inquiry, Vol. 49, Issue 1.

Baxter, L. (2011), "Capture in Financial Regulation: Can We Redirect It Toward the Common Good?", Cornell Journal of Law and Public Policy, Vol. 21, Issue 1.

Bazot, G. (2014), "Financial Consumption and the Cost of Finance: Measuring Financial Efficiency in Europe (1950-2007)", Paris School of Economics Working Papers, No. 2014-17.

BCBS (Basel Committee on Banking Supervision) (2010), "An Assessment of the Long-Term Economic Impact of Stronger Capital and Liquidity Requirements", BIS, Basel.

BCBS (Basel Committee on Banking Supervision) (2011), "Global Systemically Important Banks: Assessment Methodology and the Additional Loss Absorbency Requirement", BIS, Basel.

Beck, R., G. Georgiadis and R. Straub (2014), "The Finance and Growth Nexus Revisited”, Economics Letters, Vol. 124, Issue 3.

Beck, T. (2012), "The Role of Finance in Economic Development: Benefits, Risks, and Politics", in: D. C. Mueller (ed.), The Oxford Handbook of Capitalism, Oxford University Press, New York.

Beck, T., A. Demirgüç-Kunt and R. Levine (2007), "Finance, Inequality and the Poor", Journal of Economic Growth, Vol. 12, Issue 1.

Beck, T., R. Levine and N. Loayza (2000), "Finance and the Sources of Growth", Journal of Financial Economics, Vol. 58, Issue 1-2.

Bell, B. and J. Van Reenen (2014), "Bankers and Their Bonuses”, Economic Journal, Vol. 124, Issue 574.

Berg, A. and J. Ostry (2011), "Inequality and Unsustainable Growth: Two Sides of the Same Coin?", IMF Staff Discussion Note, No. 11/08.

Blundell-Wignall, A. and P. E. Atkinson (2012), "Deleveraging, Traditional versus Capital Markets Banking and the Urgent Need to Separate and Recapitalise G-SIFI Banks", OECD Journal: Financial Market Trends, Vol. 102.

Blundell-Wignall, A. and C. Roulet (2013), "Macro-prudential Policy, Bank Systemic Risk and Capital Controls", OECD Journal: Financial Market Trends, Vol. 103.

Bolton, P., T. Santos and J. A. Scheinkman (2012), "Cream Skimming in Financial Markets", NBER Working Paper Series, No. 16804.

Bordo, M. D. and C. M. Meissner (2012), "Does Inequality Lead to a Financial Crisis?", Journal of International Money and Finance, Vol. 31, Issue 8.

Bouis, R., A.K. Christensen and B. Cournède (2013), "Deleveraging: Challenges, Progress and Policies", OECD Economics Department Working Papers, No. 1077, OECD Publishing, Paris.

Boushey, H. and C. Weller (2008), "Has Growing Inequality Contributed to Rising Household Economic Distress?", Review of Political Economy, Vol. 20, Issue 1. 
Caballero, C., A. Patarau and P. Pontuch (2014), "Institutional Features and Regulation of Housing and Mortgage Markets", Quarterly Report on the Euro Area, Vol. 12, Issue 3.Cai, J., K. Cherny and T. Milbourn (2010), "Compensation and Risk Incentives in Banking and Finance", Economic Commentary, No. 2010-13, Federal Reserve Bank of Cleveland.

Calvet, L., J. Campbell and P. Sodini (2008), "Down or Out: Assessing the Welfare Costs of Household Investment Mistakes", Journal of Political Economy, Vol. 115, Issue 5.

Caselli, F., G. Esquivel and F. Lefort (1996), "Reopening the Convergence Debate: A New Look at CrossCountry Growth Empirics", Journal of Economic Growth, Vol. 1, Issue 3.

Causa, O., A. de Serres and N. Ruiz (2014), "Can Growth-Enhancing Policy Lift All Boats? An Analysis Based on Household Disposable Incomes", OECD Economics Department Working Papers, No. 1180, OECD Publishing, Paris.

Cecchetti, S. G. and E. Kharroubi (2012), "Reassessing the Impact of Finance on Growth", BIS Working Papers, No. 381.

Cecchetti, S. G. and E. Kharroubi (2015), "Why Does Financial Sector Growth Crowd out Real Economic Growth?", BIS Working Papers, No. 490.

Cerra, V. and S. C. Saxena (2008), "Growth Dynamics: The Myth of Economic Recovery", American Economic Review, Vol. 98, Issue 1.

Christen, M. and R. Morgan (2005), "Keeping up with the Joneses: Analyzing the Effect of Income Inequality on Consumer Borrowing", Quantitative Marketing and Economics, Vol. 3, Issue 2.

Cingano, F. (2014), "Trends in Income Inequality and its Impact on Economic Growth", OECD Social, Employment and Migration Working Papers, No. 163, OECD Publishing, Paris.

Clarke, G. R. G., L. C. Xu and H. Zou (2006), "Finance and Income Inequality: What Do the Data Tell Us?", Southern Economic Journal, Vol. 72, Issue 3.

Coibion, O., Y. Gorodnichenko, M. Kudlyak and J. Mondragon (2014), "Does Greater Inequality Lead to More Household Borrowing? New Evidence from Household Data", NBER Working Papers, No. 19850.

Cournède, B., R. Ahrend and R. Price (2008), "Have Long-term Financial Trends Changed the Transmission of Monetary Policy?", OECD Economics Department Working Papers, No. 634, OECD Publishing, Paris.

Cournède, B. and O. Denk (2015), "Finance and Economic Growth in OECD and G20 Countries", OECD Economics Department Working Papers, No. 1223, OECD Publishing, Paris.

Davies, R. and B. Tracey (2014), “Too Big to Be Efficient? The Impact of Implicit Subsidies on Estimates of Scale Economies for Banks", Journal of Money, Credit and Banking, Vol. 46, Issue 1.

Delis, M. D., I. Hasan and P. Kazakis (2014), "Bank Regulations and Income Inequality: Empirical Evidence", Review of Finance, Vol. 18, Issue 5.

Denk, O. (2012), “Tax Reform in Norway: A Focus on Capital Taxation”, OECD Economics Department Working Papers, No. 950, OECD Publishing, Paris. 
Denk, O. (2015), "Financial Sector Pay and Labour Income Inequality: Evidence from Europe", OECD Economics Department Working Papers, No. 1225, OECD Publishing, Paris.

Denk, O. and A. Cazenave-Lacroutz (2015), "Household Finance and Income Inequality in the Euro Area", OECD Economics Department Working Papers, No. 1226, OECD Publishing, Paris.

Denk, O. and B. Cournède (2015), "Finance and Income Inequality in OECD Countries", OECD Economics Department Working Papers, No. 1224, OECD Publishing, Paris.

Denk, O., S. Schich and B. Cournède (2015), "Why Implicit Bank Debt Guarantees Matter: Some Empirical Evidence", OECD Journal: Financial Market Trends, Vol. 107.

Devereux, M., N. Johannesen and J. Vella (2013), "Can Taxes Tame the Banks? Capital Structure Responses to the Post-Crisis Bank Levies", University of Oxford and University of Copenhagen.

Edgar, T. (2007), "The Search for Alternatives to the Exempt Treatment of Financial Services under a Value-Added Tax", in R. Krever and D. White (eds.), GST in Retrospect and Prospect, Thomson Brookers, Wellington.

Égert, B. (2013), "The Efficiency and Equity of the Tax and Transfer System in France", OECD Economics Department Working Papers, No. 1038, OECD Publishing, Paris.

Elliott, D. J. (2014), "Implicit Subsidies for Very Large Banks: A Primer", Economic Studies at Brookings, Washington, DC.

ESRB-ASC (European Systemic Risk Board - Advisory Scientific Committee) (2014), "Is Europe Overbanked?", Reports of the Advisory Scientific Committee, No. 4, Frankfurt.

Everett, M., J. McNeill and G. Phelan (2013), "Measuring the Value Added of the Financial Sector in Ireland", Quarterly Bulletin, Central Bank of Ireland, April.

FCIC (The Financial Crisis Inquiry Commission) (2011), The Financial Crisis Inquiry Report, Washington, DC.

Fournier, J.-M. and I. Koske (2012),"The Determinants of Earnings Inequality: Evidence from Quantile Regressions”, OECD Journal: Economic Studies, Vol. 2012.

Furceri, D. and A. Mourougane (2012), "The Effect of Financial Crises on Potential Output: New Empirical Evidence from OECD Countries", Journal of Macroeconomics, Vol. 34, Issue 3.

Gambacorta, L., J. Yang and K. Tsatsaronis (2014), "Financial Structure and Growth", BIS Quarterly Review, March.

Gennaioli, N., A. Shleifer and R. Vishny (2014), "Finance and the Preservation of Wealth", Quarterly Journal of Economics, Vol. 129, Issue 3.

Godechot, O. (2006), "Hold-up en Finance. Les Conditions de Possibilité des Bonus Élevés dans l'Industrie Financière”, Revue Française de Sociologie, Vol. 47, Issue 2.

Godechot, O. (2012), "Is Finance Responsible for the Rise in Wage Inequality in France?", SocioEconomic Review, Vol. 10, Issue 3. 
Goldsmith, R. W. (1969), Financial Structure and Development, Yale University Press, New Haven, Connecticut.

Greenwood, J. and B. Jovanovic (1990), "Financial Development, Growth, and the Distribution of Income", Journal of Political Economy, Vol. 98, Issue 5.

Greenwood, R. and D. Scharfstein (2013), "The Growth of Finance", Journal of Economic Perspectives, Vol. 27, Issue 2.

Gu, X. and B. Huang (2014), "Does Inequality Lead to a Financial Crisis? Revisited", Review of Development Economics, Vol. 18, Issue 3.

Guiso, L., M. Haliassos and T. Jappelli (2003), "Household Stockholding in Europe: Where Do We Stand and Where Do We Go?", Economic Policy, Vol. 18, Issue 36.

Haldane, A. (2012), "On Being the Right Size", Speech to the Institute of Economic Affairs on the occasion of the 2012 Beesley Lectures at the Institute of Directors, Pall Mall, 25 October, London.

Haldane, A., S. Brennan and V. Madouros (2010), "What is the Contribution of the Financial Sector: Miracle or Mirage?", in A. Turner et al. (eds.), The Future of Finance: The LSE Report, London School of Economics.

Hermes, N. and A. Meesters (2015), "Financial Liberalisation, Financial Regulation and Bank Efficiency: a Multi-Country Analysis", Applied Economics, Vol. 47, Issue 21.

Ignatowski, M. and J. Korte (2014), "Wishful Thinking or Effective Threat? Tightening Bank Resolution Regimes and Risk Taking", ECB Working Paper Series, No. 1659.

IMF (International Monetary Fund) (2010), A Fair and Substantial Contribution by the Financial SectorFinal Report for the G-20, Washington, DC.

Jaumotte, F., S. Lall and C. Papageorgiou (2013), "Rising Income Inequality: Technology, or Trade and Financial Globalisation?”, IMF Economic Review, Vol. 61, Issue 2.

Johansson, Å., P. Kowalski, E. Olaberría and D. Pellegrino (2014), "What Explains the Volume and Composition of Trade: Industrial Evidence from a Panel of Countries", OECD Economics Department Working Papers, No. 1128, OECD Publishing, Paris.

Karabarbounis, L. and B. Neiman (2014), “The Global Decline of the Labor Share”, Quarterly Journal of Economics, Vol. 129, Issue 1.

Keen, M., R. Krelove and J. Norregaard (2010), "The Financial Activities Tax", in S. Claessens, M. Keen and C. Pazarbasioglu (eds.), Financial Sector Taxation: The IMF's Report to the G-20 and Background Material, IMF, Washington, DC.

Keys, B. J., T. Mukherjee, A. Seru and V. Vig (2010), "Did Securitization Lead to Lax Screening? Evidence from Subprime Loans", Quarterly Journal of Economics, Vol. 125, Issue 1.

King, R. G. and R. Levine (1993a), "Finance and Growth: Schumpeter Might Be Right", Quarterly Journal of Economics, Vol. 108, Issue 3. 
King, R. G. and R. Levine (1993b), "Finance, Entrepreneurship, and Growth: Theory and Evidence", Journal of Monetary Economics, Vol. 32, Issue 3.

Kneer, C. (2013), “The Absorption of Talent into Finance: Evidence from U.S. Banking Deregulation", DNB Working Papers, No. 391, De Nederlandsche Bank.

Korinek, A. and J. Kreamer (2014), "The Redistributive Effects of Financial Deregulation: Wall Street versus Main Street”, BIS Working Papers, No. 468.

Kumhof, M., R. Rancière and P. Winant (2015), "Inequality, Leverage, and Crises", American Economic Review, Vol. 105, Issue 3.

Kuttner, K. and I. Shim (2013), "Can Non-Interest Rate Policies Stabilise Housing Markets? Evidence From a Panel of 57 Economies”, NBER Working Paper Series, No. 19723.

Laeven, L. and F. Valencia (2012), "Systemic Banking Crises Database: An Update", IMF Working Papers, No. 12/163.

Langfield, S. and M. Pagano (2015), "Bank Bias in Europe: Effects on Systemic Risk and Growth," Economic Policy, forthcoming.

Law, S. H. and N. Singh (2014), “Does Too Much Finance Harm Economic Growth?”, Journal of Banking \& Finance, Vol. 41.

Leahy, M., S. Schich, G. Wehinger, F. Pelgrin and T. Thorgeirsson (2001), "Contributions of Financial Systems to Growth in OECD Countries", OECD Economics Department Working Papers, No. 280, OECD Publishing, Paris.

Levine, R. (2005), "Finance and Growth: Theory and Evidence", in P. Aghion and S. Durlauf (eds.), Handbook of Economic Growth, Elsevier, Philadelphia.

Levine, R., N. Loayza and T. Beck (2000), "Financial Intermediation and Growth: Causality and Causes", Journal of Monetary Economics, Vol. 46, Issue 1.

Mankiw, N. G., D. Romer and D. N. Weil (1992), "A Contribution to the Empirics of Economic Growth", Quarterly Journal of Economics, Vol. 107, Issue 2.

Marques, L. B., R. Correa and H. Sapriza (2013), "International Evidence on Government Support and Risk Taking in the Banking Sector," IMF Working Papers, No. 13/94.

Mattana, P., F. Petroni and S. Rossi (2014), "A Test for the Too-Big-To-Fail Hypothesis for European Banks During the Financial Crisis", Applied Economics, Vol. 47, Issue 4.

Meunier, F. (2007), "Les Hauts Salaires dans la Banque: Talent ou Collusion?", Revue Française d'Économie, Vol. 22, Issue 1.

Mian, A. and A. Sufi (2014), House of Debt: How They (and You) Caused the Great Recession, and How We Can Prevent it from Happening Again, University of Chicago Press, Chicago.

Miles, D., J. Yang and G. Marcheggiano (2012), "Optimal Bank Capital," The Economic Journal, Vol. 123, Issue 567, pp.1-37. 
Mirrlees Review (2011), Tax by Design, Oxford University Press, Oxford.

De Mooij, R. A. (2012), “Tax Biases to Debt Finance: Assessing the Problem, Finding Solutions”, Fiscal Studies, Vol. 33, Issue 4.

Noss, J. and R. Sowerbutts (2012), “The Implicit Subsidy of Banks", Bank of England Financial Stability Papers, No. 15.

OECD (2007), Fundamental Reform of Corporate Income Tax, OECD Tax Policy Studies, No. 16, OECD Publishing, Paris.

OECD (2012), OECD Employment Outlook 2012, OECD Publishing, Paris.

OECD (2014a), "New Approaches to Economic Challenges: The Financial Stream", Meeting of the OECD Council at Ministerial Level, 6-7 May 2014, Paris.

OECD (2014b), OECD Economic Surveys: Turkey 2014, OECD Publishing, Paris. DOI: http://dx.doi.org/10.1787/eco surveys-tur-2014-en

Ollivaud, P. and D. Turner (2014), "The Effect of the Global Financial Crisis on OECD Potential Output", OECD Economics Department Working Papers, No. 1166, OECD Publishing, Paris.

Pagano, M. and G. Pica (2012), "Finance and Employment”, Economic Policy, Vol. 27, Issue 69.

Philippon, T. and A. Reshef (2012), "Wages and Human Capital in the US Finance Industry: 1909-2006", Quarterly Journal of Economics, Vol. 127, Issue 4.

Piketty, T. (2014), Capital in the Twenty-First Century, Harvard University Press, Cambridge, MA.

Poddar, S. (2007), "VAT on Financial Services: Searching for a Workable Compromise", in R. Krever and D. White (eds.), GST in Retrospect and Prospect, Thomson Brookers, Wellington.

Poddar, S. and M. English (1997), "Taxation of Financial Services under a Value-Added Tax: Applying the Cash-Flow Approach", National Tax Journal, Vol. 50, Issue 1.

Pollin, R. (1988), "The Growth of U.S. Household Debt: Demand-side Influences", Journal of Macroeconomics, Vol. 10, Issue 2.

Rajan, R. G. (2010), Fault Lines: How Hidden Fractures Still Threaten the World Economy, Harper Collins, New York.

Rajan, R. G. and L. Zingales (1998), "Financial Dependence and Growth", American Economic Review, Vol. 88, Issue 3, pp. 559-586.

Rousseau, P. and P. Wachtel (2011), "What is Happening to the Impact of Financial Deepening on Economic Growth?”, Economic Inquiry, Vol. 49, Issue 1.

Sahay, R., M. Čihak, P. N'Diaye et al. (2015), "Rethinking Financial Deepening: Stability and Growth in Emerging Markets," IMF Staff Discussion Note, SDN/15/08, May.

Saiki, A. and J. Frost (2014), "Does Unconventional Monetary Policy Affect Inequality? Evidence From Japan", Applied Economics, Vol. 46, Issue 36. 
Schich, S. and Y. Aydin (2014), "Policy Responses to the Issue of Implicit Bank Debt Guarantees: OECD Survey Results", OECD Journal: Financial Market Trends, Vol. 104, OECD Publishing, Paris.

Schich, S., M. Bijlsma and R. Mocking (2014), "Improving the Monitoring of the Value of Implicit Guarantees for Bank Debt", OECD Journal: Financial Market Trends, Vol. 106, OECD Publishing, Paris.

SNA (1993, 2008), System of National Accounts, European Commission, IMF, OECD, United Nations, World Bank.

Sutherland, D., P. Hoeller, R. Merola and V. Ziemann (2012), "Debt and Macroeconomic Stability", OECD Economics Department Working Papers, No. 1003, OECD Publishing, Paris.

Thewissen, S., C. Wang and O. van Vliet (2013), "Sectoral Trends in Earnings Inequality and Employment, International Trade, Skill-Biased Technological Change, or Labour Market Institutions?", LIS Working Paper Series, No. 595.

Tobin, J. (1984), “On the Efficiency of the Financial System”, Lloyds Bank Review, Vol. 153.

van Treeck, T. (2014), "Did Inequality Cause the US Financial Crisis?", Journal of Economic Surveys, Vol. 28, Issue 3.

Trew, A. (2008), "Efficiency, Depth And Growth: Quantitative Implications of Finance and Growth Theory", Journal of Macroeconomics, Vol. 30, Issue 4.

UNECE (United Nations Economic Commission for Europe) (2011), Canberra Group Handbook on Household Income Statistics: Second Edition, United Nations, Geneva. 